\title{
Margaret Mahy and the Golden Age of Children's Literature
}

\author{
by

\section{Catherine Proffitt}

\author{
A thesis \\ submitted to the Victoria University of Wellington \\ in fulfilment of the \\ requirements for the degree of \\ Master of Arts \\ in English Literature
}

Victoria University of Wellington

2011 


\section{Contents}

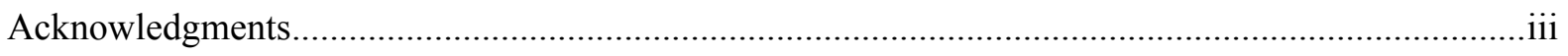

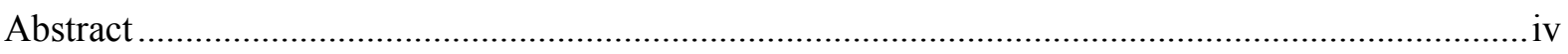

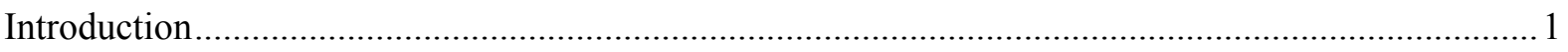

Chapter One: Wonderland in The Changeover and The Tricksters ............................................... 11

Chapter Two: Imaginary Islands in Dangerous Spaces and Kaitangata Twitch ................................ 31

Chapter Three: Forest-gardens and storybook houses in Dangerous Spaces and The Tricksters.........56

Chapter Four: Cultivating Heroes: The Forest-Garden in The Other Side of Silence ...........................69

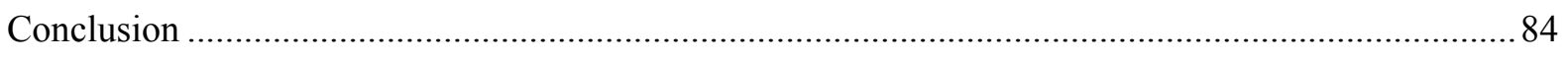

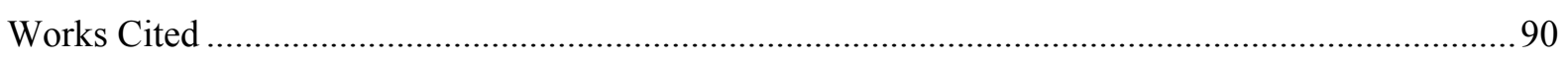




\section{Acknowledgments}

My first thanks must go to my excellent supervisors, Associate Professor Kathryn Walls and Dr. Anna Jackson for their encouragement, patience and extremely helpful editorial advice. My thesis topic was sparked by the Honours courses in New Zealand and Victorian children's literature that they teach, so I would like to thank them for the inspiration as well.

Heartfelt thanks go to Theresa Crewdson, for proof reading my thesis with thoroughness and diligence. Thanks to Michael Pohl too, for helpful feedback on earlier draft chapters.

I would also like to thank Mike Playle and Jen Brown for allowing flexible work arrangements to support my academic endeavours.

Finally, I would like to thank my family (especially my parents) and my friends, who have been supportive even as they have been bemused by my incessant Mahy ramblings. I am particularly grateful to Lilja, my office mate, for good conversation, to Alan for the encouragement and interest shown, and to James, for being there when I was at the sharp end of things.

Catherine Proffitt

Wellington

June 2011 


\begin{abstract}
Margaret Mahy's novels contain numerous allusions to the classics of Victorian fiction for children. Some of these take the form of passing references; in 24 Hours, for example, protagonist Ellis thinks of himself as "Ellis in Wonderland." But Mahy also draws on Victorian precedents for some of her settings, taking imaginary islands from Peter and Wendy and Treasure Island, and the secret garden from Frances Hodgson Burnett's novel of the same name. She also invokes the forest of the fairy tales that (although they were not invented by the Victorians) featured so prominently in the reading of Victorian children. To date, little attention has been paid to what might be described as the "Victorian dimension" of Mahy's work. In what follows, I examine its function in five novels. It emerges that Mahy's response to the values embodied by her Victorian texts is critical on at least three counts. Mahy's heroines (or, rather, female heroes) reject the passivity and silence exhibited by fairytale characters such as Jorinda in the Grimms' 'Jorinda and Joringel', and the lack of emotional growth displayed by Lewis Carroll's Alice. They are also shown in the process of leaving childhood (nostalgically idealized by Carroll, J.M. Barrie and other Victorian authors) behind. Moreover, this thesis exposes the tension between Mahy's insistent allusion to quintessential fantasy spaces such as Wonderland on one hand, and the distinct anxiety present in her work about the dangerously isolating nature of fantasy on the other. While for Mahy's teenage protagonists the domestic "real" wins out more often than not over the fantastic but dangerous "true", the transformative journey of maturation that each undergoes is figuratively sparked by their belief in the Red Queen's “six impossible things before breakfast”. Perhaps by the same token, they learn that fantasy worlds (like Barrie's "Neverland") can be dangerously isolating.
\end{abstract}




\section{Introduction}

$\ldots$ the underlying story - the deep story - was never mine in the first place, but existed like some platonic form.

(Margaret Mahy, quoted in Duder, 255)

Sarah Fiona Winters observes that Margaret Mahy's young adult novels show 'how the human place of New Zealand, and the human place of the adolescent body [...] are both haunted by European history, European literature, and European families' (422). More precisely, Mahy's work is haunted by Victorian literature for children. Francis Spufford has described Mahy's supernatural novels The Changeover (1984), The Haunting (1982) and The Tricksters (1986) as 'Brontë-esque' (171), and Victorian influences have been similarly discerned by Rose Lovell-Smith in her detailed account of the Gothic element in The Tricksters. Yet no critic has given sustained attention to Mahy's allusions to the classics of Victorian children's literature.

These allusions are copious. I use the term 'allusion' in its widest sense here, as Mahy uses both explicit references and quotations to indicate the presence of the Victorian children's texts, as well as recurring motifs with a Victorian resonance: imaginary islands, looking glasses, fairytale forests and secret gardens. Works such as Peter and Wendy (1911) and Alice's Adventures in Wonderland (1865) have passed into popular culture to such an extent that even if Mahy's readers have not read Barrie and Carroll's novels, they will have at least a passing familiarity with the characters and storylines in them from other treatments. By alluding to Victorian children's novels, Mahy establishes a familiar starting place for the reader. It is as if for Mahy, Victorian children's literature epitomises childhood, the platform 
from which heroines such as Laura and Hero must leap in order to progress towards maturity.

Mahy alludes frequently to Lewis Carroll's Alice books. Ellis, the protagonist in 24 Hours (2000) even refers to himself as 'Ellis in Wonderland' (192). Other novels are haunted by the spectre of the Cheshire cat, used often by Mahy to evoke mystery or secrecy. Jess Ferrett, the enigmatic protagonist of Mahy's 2002 novel Alchemy, has a 'Cheshire cat grin', as does Athol in The Other Side of Silence (1995), in reference to his secret life as a writer (77). Similarly, the Carnival brothers' mysterious appearance in The Tricksters is foreshadowed by the Cheshire-like smile of the Hamiltons' actual cat, Crumb, who smiles 'enigmatically at [Harry] like a cat that has seen it all but will tell nothing' (69).

References to Carroll's novels are found also in The Tricksters and The Changeover. Discussing with her siblings the Christmas presents they might like, Harry Hamilton tells them she would like a book:

“It's a special book, this one," Harry said. [...] "As you read my book you alter the world. You read Chapter One, look up from its pages and - hey presto - things have changed." "Like Alice in Wonderland?” asked Serena, interested (33).

Martin Gardner uses the term 'entantiomorphs' to describe Tweedle Dum and Tweedle Dee in the famous The Annotated Alice (208); interestingly Mahy uses the same term on page 92 to describe twins Felix and Hadfield Carnival, two of the titular tricksters. Later, when Harry accuses Felix of being 'a snark', Felix doesn't know the reference, so Harry explains 'They're in a book by Lewis Carroll' (162). 'I can believe six impossible things before breakfast' (94), remarks Anthony, a visitor to the Hamilton's beach house. This claim, also uttered by Sorry in The Changeover (120), quotes Carroll's Red Queen. In what is very probably a Carrollian allusion, both Sorry and Laura are constantly associated with mirrors, 
or 'looking-glasses'. Sorry has 'looking-glass eyes' (13), and is able to recognise himself as a witch because he 'could go through the looking-glass and the others couldn't' (169). Laura also, in a sense, goes 'through the looking-glass'. The novel opens with Laura catching sight of herself in the mirror, her reflection 'look[ing] back at her from some mysterious place alive with fears and pleasures she could not entirely recognise' (4). More explicitly, Laura identifies with Alice during her 'changeover' ordeal of becoming a witch: 'Like Alice she did not think she would ever be small enough to reach the beautiful garden. "Even if my head did go through," [Laura] whispered, "it would be very little use without my shoulders"” (226).

The Other Side of Silence is likewise full of allusions to Victorian works. The novel's enclosed, overgrown garden echoes that which Mary Lennox discovers in Frances Hodgson Burnett's classic book for girls. The garden in Mahy's novel is in fact referred to as 'the secret garden' by protagonist-narrator Hero, near the opening of the book. In Burnett's novel the garden is locked after the death of Colin's mother Lilias; similarly we learn from Miss Credence, owner of the garden in Mahy's novel, that 'it really was a beautiful garden when I was a child [...] But then, after my mother died, people stopped coming in' (160). The Other Side of Silence also resonates with Rudyard Kipling's The Jungle Book (1894). Hero identifies with Mowgli due to their mutual lack of spoken language; she reflects:

In The Jungle Book, Mowgli is brought up by wolves and talks to wolves. There really have been wild children who have lived among animals, but no girl brought up among trees would learn to sing and fly like a bird (80). 
Collectively, fairytales, too, are a key intertext in this novel (as they are in many other Mahy novels, notably The Changeover). ${ }^{1}$ Miss Credence's house 'looked like a house in a story book' (4), while Hero is given the nickname 'Jorinda, Queen of the Bird People', a reference to the Grimm Brother's tale 'Jorinda and Joringel'. Hero herself refers to her collection of fairytales as a kind of reference book 'for secret advice... for divination' (8), and even declares that it is the book that most represents her: 'Supposing I had been turned into a book back then, [...] I would probably have turned into Old Fairy Tales, which was the book everyone read to me when I was small' (8). As the novel reaches its climax, it alludes to 'Bluebeard', 'the tale of a bride who was allowed to go anywhere in a house except for one forbidden room'. Like Bluebeard's wife, Hero can't 'resist going into that room' (120), even though she dreads what she might find there.

Several of Mahy's novels display the influences of classic island narratives from children's literature. Sailing features in novels such as The Tricksters, Kaitangata Twitch and Dangerous Spaces, evoking the ubiquitous sea voyage in island adventure stories. The protagonist of The Tricksters, Harry, is identified as 'the Robinson Crusoe of a doll's-house island' (97) when she kayaks to one of the many small islands that litter the coast surrounding Carnival's Hide. Perhaps the idea of pirates in Treasure Island and Peter and Wendy particularly captured Mahy's imagination; for while there are no actual pirates in her novels for young adults, they feature strongly in her picture books and novels for younger readers. ${ }^{2}$ The piratical atmosphere is heightened in The Tricksters when Harry's sister Christobel identifies herself with a unnamed character from Treasure Island, joking 'Aye, it'll be a

\footnotetext{
${ }^{1}$ As I explain in Chapter 3, I have considered fairytales such as Perrault's 'Bluebeard' and the Grimms' 'Jorinda and Joringel' as part of the Victorian canon of children's literature, owing to their popularisation during that period.

${ }^{2}$ See for instance: novels The Pirate Uncle (1977), The Great Piratical Rumbustification (1981), and picture book The Man Whose Mother was a Pirate (1976).
} 
fearsome, rough day for the poor souls at sea, Jim lad' (199). She is ostensibly expressing sympathy for her brother Charlie out yachting in bad weather, but also unwittingly foreshadowing the emotional storm the family is about to enter as dark secrets are revealed. Meanwhile, father of the family, Jack, is reading The Coral Island by R.M. Ballantyne (207) to the younger children, or perhaps more to himself considering the very young age of some of his listeners (Tibby is only two years old). As the villain in the family drama, Jack seems to be escaping into the fictional world of the Polynesian island, where another Jack (Ballantyne's character Jack Martin) is able to avoid family responsibilities in favour of fighting pirates.

Her immersion in Victorian sources notwithstanding, Mahy uses 'Golden Age' material to contrast Victorian 'childhood' against a contemporary view of adolescence (teenage girlhood in particular). Mahy's heroines are only a few years older than the protagonists of Carroll, Barrie, Stevenson and Burnett, yet they are clearly young adults. They drink, drive and make love, while the protagonists of the Golden Age novels are both children and child-like. ${ }^{3}$ Since critics of Mahy's work have largely been occupied with the theme of adolescence rather than childhood, it is little wonder they have overlooked the allusions to seven-year-old Alice or ten-year-old Mary Lennox.

Identifying adolescence as Mahy's essential theme, critics such as Adrienne E. Gavin, Josephine Raburn, Lissa Paul, Claudia Marquis, Allison Waller and Anna Smith have

\footnotetext{
${ }^{3}$ Of course, the concern of young sexuality, while never explicitly mentioned, does bubble to the surface in novels such as Peter Pan and The Secret Garden. Despite Wendy's demure nature, Tinkerbelle's jealousy of Wendy's relationship with Peter is clearly sexual. The Secret Garden, as Timothy Morris points out, is 'elaborately sexual, without directly invoking the sexuality of Mary Lennox.' Morris goes on to note that 'the appeal of the garden as shorthand for the unseen workings of women's sexuality is so pervasive that Nancy Friday could borrow the title of the novel for her 1973 collection of women's sexual fantasies without making any explicit reference to Burnett $[\ldots]$ as if the sexual undercurrents of the novel were so well understood that the only possible title for a book about what women think during sex, but won't tell their lovers, must use the phrase Secret Garden' (Morris, 93).
} 
focused on the adolescent protagonists' development of personal agency or power, often remarking on the parallel between the heroines' burgeoning sexuality and their development of supernatural abilities. For Raburn, Paul and Marquis, Mahy's treatment of adolescence is feminist; that is to say her female protagonists develop a sense of their own identities during their adolescence rather than being passive objects destined merely for marriage. For Raburn, The Changeover is something of a revolution:

Laura's story may be a first in feminine fantasy, because it establishes a formula which explains the female psyche and coming of age. It shows what heroines may become, not what males wish them to be. Laura is a true heroine who comes into her own with the help of a young man, but much through her own power (37).

Marquis agrees, arguing (in relation to a broader selection of texts) that:

[Mahy] never sublimates woman's experience into an experience that simply supports male social interest. In her writing she makes ideology visible by giving to her female characters a distinctively female variety of power. That is to say her women collectively and individually make claims for themselves that stand against the view of culture at large. From Troy in The Haunting, to Laura in The Changeover, to Garland in Maddigan's Fantasia (adolescent fiction) maturation means freedom to enjoy newly discovered power. (“Strong Characters” NP)

Yet the girls' heroism is not merely male heroism in drag. Treasure and glory are not the end goals here, as they are for Jim Hawkins and other male heroes of the romance tradition. Instead, as Lissa Paul notes, 'Laura's quest is personal and domestic; she fights for someone she loves. [...] The values in Mahy's book are connected with individual humanity 
rather than public glory' (Paul, 198). Thus the introduction of the familial and the domestic does not diminish the heroism of Mahy's protagonists, but instead enhances it.

Allison Waller examines the transformational power of magic for Mahy's heroines, noting that 'accepting magical powers and extending their rewards to others can reflect elements of growing up in these texts' (24), though she also goes on to stress that 'being a witch provides a metaphor for adolescence, not adulthood' (25). As other critics such as Anna Smith (2005) have noted, magical powers are associated with maturing bodies and burgeoning sexuality, imagination, creativity, and the ability to overcome others, indeed, those aspects of adolescence that may be, in Waller's words, 'mysterious', 'dangerous, threatening and full of potential' (41). At the same time, Mahy avoids the traditional literary representations of witches as depraved, perverse or reviled. Thus, adolescence and the process of becoming a witch are both established as positive transformations. Yet if, as Smith and Waller suggest, magic is associated with adolescence, it must inevitably be abandoned as adulthood is reached, much as Mahy suggests an over-reliance on fantasy must be abandoned, a notion I shall return to in subsequent chapters.

The theme of adolescence is also analysed by critics writing about Mahy's less magical heroines. Smith, for instance, frames her discussion of Hero's movement between childhood and adolescence in The Other Side of Silence in terms of Mahy's distinction between the true and the real. She argues that to pass into and through adolescence successfully, Hero must be able to 'see' both the fantastical, mythical 'true', and the quotidian but necessary 'real'. For Hero to perceive the extent to which her elective mutism imprisons and infantilises her, she 'needs the eye of truth found on the other side of silence to see how reality can be twisted and transformed, and how fantasy can be imprisoning as well as protecting' (Smith, 52). 
Thus, my investigation of the very conscious relationship between Mahy's novels and their Victorian antecedents works to support the critical consensus outlined above. Mahy's departure from the more limited roles for girls found in the Victorian and fairytale sources is emphasised by the agency she affords her female protagonists (magical or not). Mahy first evokes and then dismisses the passivity and enforced silence of Victorian and fairytale heroines in favour of a much more active form of girlhood; not only are Laura and Hero bravely rescuing others (Laura rescues her brother Jacko from incubus Carmody Braque, while Hero helps to free intellectually-disabled Rinda from her mother's imprisonment), but they are rescuing themselves along the way. As implied by her name, Hero eventually abandons her elective mutism, telling the reader in her narrator role that 'in time I would break free from the spell [of mutism], not because some Joringel would appear to touch me with a blood red flower and rescue me, but because I was my own magician and had the power to rescue myself' (The Other Side of Silence, 115).

In his seminal study of Golden Age works, Humphrey Carpenter argues that selected Victorian children's authors were concerned above all with what he calls 'the search for a mysterious, elusive Good Place' (13). According to Carpenter, Barrie and the others rejected the afterlife conceived of by conventional Christianity, instead seeking and constructing heaven-like alternatives in the 'other worlds' of Neverland, Wonderland and the secret garden. For Carpenter, these other worlds are pre-lapsarian, where children can remain innocent and the impending taint of adulthood can be escaped, at least for a time. In contrast, Mahy projects a positive attitude towards growing up. While Mahy's protagonists do visit other worlds (like the secret garden) such worlds do not represent an escapist goal in themselves. Rather, after allowing the protagonists to discover their identity, the fantasy space is jettisoned. Where the Golden Age authors champion their protagonists' escape from 
adult control, Mahy emphasises that adulthood, especially womanhood, is an achievement to be strived for.

Consequently, Mahy shows the limitations of fantasy spaces. We see repeatedly how her protagonists' escapist fantasies of solitude and authority turn out to be corrupted and dangerous: in Kaitangata Twitch, Meredith's dream island is bloodthirsty and terrifyingly alive, Anthea's island visions in Dangerous Spaces represent a retreat into suicidal fantasy, while in The Other Side of Silence, Hero's dream garden symbolises her dangerous disconnection from her family. An over-reliance on fantasy is persistently associated with an unhealthy level of self-isolation or passivity. Conversely, the increasing irrelevance of fantasy becomes a mark of Mahy's protagonists' growing maturity. Anthea no longer needs her dreamland Viridian once she starts to form closer relationships with her family, while both Harry in The Tricksters and Hero burn their fantasy novels as a symbol of their reintegration with their respective family units.

Yet, despite the danger, the intrusion of fantasy into the lives of Mahy's protagonists is usually what spurs them to reach out to others in the real world. Mahy's novels do not, then, represent a total shift from the escapist worlds of the Golden Age towards realism. Instead, the novels studied here intertwine the fantastic with the real, encouraging far greater psychic development for her protagonists than can be seen in characters such as Carroll's Alice, who moves between two separate, parallel worlds and demonstrates curiously little emotional growth. If the Golden Age literature established the association between fantasy and childhood (and correspondingly, between reality and adulthood), then Mahy's characters allow us to understand the fantastic or 'supernatural' as a projection of their internal perspectives, or what Claudia Marquis calls the 'psychic condition of adolescence' ("Ariadne 'Down under"' 64). Perhaps Mahy's implication is that since adolescence occupies a liminal 
space between childhood and adulthood, neither realism nor fantasy is in itself sufficient as a narrative for this transition.

Mahy's protagonists do not become overtaken by another character in their own story, as Mary Lennox does in The Secret Garden (implying that Mary's development has really been for Colin's benefit), nor do they disavow adult responsibilities to live in a fantasy world, as Alice and Peter Pan do. Neither do they become callous like Peter or Jim Hawkins, murderers both. Instead, Mahy's protagonists recognise the responsibilities inherent in their powers and resist becoming corrupted by them. Unlike the Victorian protagonists, who exhibit little ability to reconcile their symbolic 'other-world' experience with reality, Mahy's heroines become able to balance their (potentially dangerous) fantasies of escape with the demands of family life. They develop empathy as they do so, a characteristic largely missing from protagonists such as Alice or Jim Hawkins. Mahy's narrative technique of intertwining fantasy and realism echoes her constant theme of integration and unity. Many of her novels have in common a focus on integration; both of the fractured and disparate parts of the self, and of social reintegration into the family unit or through sexual relationships with others. For Mahy, integration and the ability to perceive both fantasy and reality are the keys to successful passage through adolescence, and enable her protagonists to escape Victorianesque fantasy islands and wonderlands that threaten entrapment and entropy rather than signifying liberation and growth. 


\section{Chapter One}

\section{Wonderland in The Changeover and The Tricksters}

Lewis Carroll observes in the preface to Sylvie and Bruno that 'perhaps the hardest thing in all literature - at least $I$ have found it so: by no voluntary effort can I accomplish it: I have to take it as it comes - is to write anything original' (6). Despite Carroll's lack of confidence in his ability to write with originality, his classics Alice's Adventures in Wonderland (1865) and Through the Looking-Glass (1871) have had an enormous influence on fantasy authors for children. Indeed, Jackie Wullschlager considers Carroll's influence so significant that 'Wonderland, with its own distinct landscape, language, logic, people; its precise physical characteristics' has become 'the prototype for the escapist worlds of subsequent children's fantasies' (55). The work of Margaret Mahy is no exception; it is clear to anyone with even a passing familiarity with Carroll's Alice works that they have been a rich resource for Mahy in her writing for adolescents. Looking-glasses, dreamscapes, Cheshire cat grins and chessmen, amongst other things, abound.

This chapter focuses on The Changeover and The Tricksters, investigating Mahy's use of the Wonderland motif and the connections this has with her themes of storytelling and personal agency for her adolescent protagonists. ${ }^{4}$ However, a brief survey of a selection of Mahy's young adult novels yields copious reference points, both direct quotes and deeper analogies.

An obvious starting point is 24 Hours, in which Mahy puns on the main character's name, tagging him as 'Ellis in Wonderland' (192). Although 24 Hours is on one level a

\footnotetext{
${ }^{4}$ Unless specifically mentioned, I use 'Wonderland' as shorthand to describe the other worlds of both Wonderland and Looking-Glass land, as Mahy often uses aspects from both as touchstones in her novels, almost as if they are a single work. I have used Gardner's 1960 edition of The Annotated Alice (which contains both works) for page references, and where necessary, have identified the work concerned.
} 
realist novel - that is, without the witchcraft or supernatural powers that appear in many of Mahy's novels - Wonderland is evoked to describe the strange turn Ellis's life takes when he meets the Hammond sisters. He plunges from his middle-class, schoolboy life into the underbelly of the city, discovering alcohol, fast cars and lust along the way. The reader is alerted to the parallel between Ellis's journey into the city of adulthood and Alice's adventures when Ellis catches a glimpse of himself in a looking-glass, where he sees a 'reflection [which] had seemed to belong to someone older than seventeen' (11). Mahy's use of the old-fashioned term 'looking-glass' more often than the more commonplace 'mirror' must be deliberately Carrollian.

Mahy repeats the looking-glass motif in The Changeover and The Tricksters. In the opening pages of those novels, we see Laura and Harry each looking into a mirror, to be greeted by a vision of their more mature, more powerful, somehow more essential selves, as if their reflections have already been through the journey of self-discovery represented by Wonderland and are looking back from the other side. For Ellis (as with Laura and Harry), this reflection of his older self is one of the catalysts for change: 'It begins now!' (11). After unexpectedly attending a 'separation' party hosted by friends of his parents, Ellis ends up with the Hammonds at their strange home, a former motel whose name, 'Land-of-smiles' suggests a fairy world or Wonderland that contrasts ironically with its dilapidated reality. As the party carries on at the new location, Ellis meets a stream of surreal characters as peculiar as any that Alice encounters, except that they are not figures of fantasy: Phipps, the tattooed man who speaks in riddles; another, covered in body piercings, whose 'gesturing hands, also covered in rings, seemed more like metallic robot hands than those of an ordinary man' (51); Monty, the Hammonds' guardian, 'a grey-haired man lean[ing] back in a carved throne of a chair - a chair so tall and wide that it dwarfed him, making the rest of the room seem slightly 
out of proportion, like a doll's-house kitchen' (52). This is not to mention the Hammond girls themselves, whose animal names - Ursa (bear), Leo and Fox - align them with the anthropomorphic Dormouse, Lion and Unicorn that Alice comes across. The association with Wonderland is further underlined by Mahy's reference to the Mad Hatter's tea party scene:

“... More coffee?"

“He hasn't had any yet, so he can't have more," said Fox, and then both sisters spoke together in a ragged chorus.

"It's very easy to have more than nothing," they cried, and then they laughed together. Ellis did not know what to say to any of this. It sounded familiar, almost Shakespearian. (59-60)

Intriguingly, although the reference is familiar to Ellis he can't quite pick the source; he doesn't yet realise he is 'Ellis in Wonderland', although the reader might. After the party, at which Ellis gets drunk for the first time, he wakes up in a spare room at the Land-of-Smiles with a sense of having forgotten who he is. Like Alice, he asks 'who am I?' (74). Certainly he is sure that he is not the same person he was the day before, a feeling that, according to Gardener, also characterises Alice's journey (138).

An explicit allusion to the Mad Hatter's tea party also features in The Other Side of Silence, in which the Rapper family's breakfast table is 'like the Mad Hatter's tea party with everyone having to move one place further on in order to make room' (133). Here, the crowded breakfast table is symbolic of protagonist Hero's feelings of being overcrowded by newcomers and going unnoticed in a family full of talkers. "No room! No room!" the March Hare and the Hatter cry out when Alice approaches the table (93). Hero's solution to the 
same situation is to find room for herself in the treetops and gardens of Miss Credence's house.

More firmly in the realm of fantasy is Dangerous Spaces, where a connection to Wonderland is suggested more subtly than through the direct literary references of 24 Hours and The Other Side of Silence. In this novel, protagonist Anthea enters through sleep a Wonderland-like dreamscape, known as Viridian. The landscape of Viridian is constantly changing. Just as Alice finds in her journey in Looking-Glass land, distances in Viridian are illusory: 'she was surrounded by a whiteness that made big distances seem small and small distances seem immense' (38). Anthea can cross a mountain in a day, only to find her destination remains hopelessly out of reach. The battle that perpetually haunts Viridian, which 'shifts around' and 'goes on forever' (100), recalls the on-going and futile fight for the crown between the Lion and Unicorn, who are 'in such a cloud of dust, that at first Alice could not make out which was which' (Gardner 283). ${ }^{5}$

Despite these peculiarities, Viridian seems real to Anthea while she is in it. Like Alice, Anthea becomes increasingly unable to distinguish between dream and reality; Alice's anxiety that she may be merely a figure in the Red King's dream parallels Mahy's suggestion that Viridian has become Anthea's reality while her real life has become the dream. Flora, Anthea's cousin and the novel's second protagonist, enters Viridian as purposefully as Alice enters Looking-Glass land; although Mahy plays with this idea by having Flora use a different kind of optical device as a portal - a stereoscope rather than a mirror. ${ }^{6}$ In any case, the mirror aspect is played up by Mahy's use of dual protagonists of the same gender and age,

\footnotetext{
${ }^{5}$ The fight between the Lion and the Unicorn is futile because the crown actually belongs to the King, who would not relinquish it even in the event a winner of the fight was declared.

${ }^{6}$ Of course, a stereoscope looks out rather than in; perhaps the suggestion here is that the girls need to look outside of themselves towards the other before they can look at themselves.
} 
who start out as opposites in appearance, personality and lifestyle, but who learn to empathise with one another.

While allusions to Alice in Wonderland pepper many of Mahy's novels, the motif of the symbolic journey to and from Wonderland is most strongly paralleled in The Changeover and The Tricksters. Mahy, drawing from Wonderland a template for her protagonists' journey to other worlds, frames each transition, as Carroll does, with storytelling and fiction. Although, according to Carolyn Sigler, 'the Alice books have consistently been read as portrayals of the experience of growing up and the construction of agency and identity' (xiv), Mahy's adolescent protagonists (as I hope to show) undergo far greater identity development than Alice. While Carroll's looking-glass may be considered a window on the absurdity of the world and adult life, Mahy's is the doorway into the self.

Alice's journey through the looking-glass is evoked from the outset of The Changeover. Laura's reflection seems to be someone other than herself, or rather, a different, more evolved version of herself looking back at her from in the mirror: 'the face was not her face for it knew something that she did not. It looked back at her from some mysterious place alive with fears and pleasures she could not entirely recognise' (4). Laura is able to identify this premonition because she is a 'sensitive', someone able to sense change in a supernatural way:

“Warning!" insisted Laura [...]

"First the look of everything changes... things stop flowing into each other and stand separate, a bit silly-looking but scary. The world gets all accidental. It's as if you had a house which seems to stay up by being propped up against itself and suddenly you realised nothing was really touching after all". She slowed her voice down. 
"The weekend Dad left with his girlfriend I had warnings..." (8)

Interestingly, Laura's description of the feeling she gets during a warning is evocative of Wonderland itself - an 'accidental' world built like a house of cards, where feelings of confusion and isolation dominate. Laura soon discovers the meaning of the warning when her younger brother Jacko falls mysteriously ill. It is no ordinary childhood illness, however, for Jacko has fallen under the malignant spell of the vampiric Carmody Braque, a lemure, or ancient evil spirit impersonating a human being, able to suck the life force out of others in order to achieve immortality. Laura's 'sensitive' nature leads her to seek out Sorry Carlisle, a schoolmate whom she recognises as a male witch. Sorry's mother and grandmother, also witches, suggest that the only way to stop Carmody Braque from consuming Jacko completely is for Laura to undergo a 'changeover', or become a witch herself. It is during the changeover ordeal that Laura enters her version of Wonderland. Desperation is what precipitates Laura's journey, rather than the curiosity that triggers Alice's.

The changeover ritual takes place at the Carlisle house, the aptly named Janua Caeli (meaning Gates of Heaven). Laura intuitively invokes the name of the house 'like a spell' (57) when she finds the gates locked. The bolt pinches her hand as it yields, foreshadowing the psychic pain she will undergo during the changeover; as the gates open, Laura literally crosses the threshold into a new part of her life. From the moment Laura steps onto the grounds of the house, 'into a courtyard that appeared to be full of giant chessmen' (58), the idea of Wonderland is suggested. In Through the Looking-Glass, Alice must win the game of chess to complete her journey and return home, and in order to win the game she must become a figure of power - the Queen. The appearance of the chess motif suggests that Laura must do the same, but rather than become a Queen, she becomes a different feminine figure of power - a witch. The difference is significant; Alice ultimately rejects the 
responsibilities of being Queen, demonstrating her lack of maturity, while Laura's symbolic transformation into a witch causes her to become more aware of her adolescent identity. As Anna Smith argues:

being a witch opens up knowledge and insight. [...] In Mahy's texts the primary knowledge of witchcraft is a recognition of the spiritual and magical elements in the world, but the deeper knowledge this brings is of identity, status and role, power and its responsibilities: all processes of awareness that signify the developmental stage of adolescence (30).

The changeover ritual is itself loaded with imagery drawn from Carroll's work. ${ }^{7}$ I have noted earlier the importance of the literal looking-glass in warning Laura about her impending change. For Mahy, being able to 'pass through the looking-glass' and all that that implies with respect to transitions and self-reflection seems to be a key part of being a witch and thus achieving a personal sense of identity and power. Sorry, Laura's guide through the ritual, is described as having 'looking-glass eyes' (13). He later explains to Laura that he knew he was a witch because he 'could go through the looking-glass and the others couldn't' (113). In fact, Sorry can be seen as something like Laura's reversed mirror-image - he represents cold reason to her emotion, affluence to her poverty, a male witch to her female. Seeing her reflection, 'tiny and flaring, with light on the silver surface' of Sorry's lookingglass eyes, Laura rallies her courage, accepting that 'she [must] be brave and do what it was shown to her to do' (142). It is therefore apt that Laura must pass through the looking-glass as the entry point to her changeover:

\footnotetext{
${ }^{7}$ It is also full of mythic, folkloric and fairytale iconography, some of which I will deal with in Chapter 5 of this thesis.
} 
... she looked into the watery depths of the looking-glass where she saw herself, shadowed and delicate, her wrists and ankles as slender as if she had hollow bird bones and could rise up against gravity, her woolly hair a dark halo, glittering as if touched by gold dust, her eyes like black holes burnt into a smooth olive face. She licked her lips and would not have been surprised to see a serpent's tongue flicker between them, but it was her own tongue, surprising because it showed she was solid all the way through and not just a phantom created by Miryam and the night.

"Not that it will be easy for you," Miryam continued. "But for the moment - look it's a wonderful, mysterious thing to be a girl.'

And, looking at her reflection, Laura thought this might be true (138).

Interestingly, the serpent image used here by Mahy is also applied to Alice, who is mistaken for one by a pigeon after one of her many changes in size has left her with 'an immense length of neck' which 'would bend about easily in any direction' (Alice, 74). Rose Lovell-Smith points out that the serpent image in Carroll is associated both with Alice's confusion over her own identity and also a satirical comment on Darwin's system of species classification, whereby animals classify humans rather than the other way around ("Eggs and Serpents" 39). Mahy, on the other hand, introduces the image in acknowledgment of Laura's powerful dark side. Alice becomes confused about whether she is a serpent or a little girl, while Laura manages to resist this confusion to her own surprise, instead reconciling her real self and her reflection, the light and the dark, to become 'solid all the way through'.

Laura's changeover dreamscape has frequent parallels to Wonderland. As Alice discovers at the Mad Hatter's tea party where it is 'always six o'clock' (99), the conventional rules of time and space are not valid in Wonderland. The same is true for Laura; once through into the changeover dreamscape she 'could not be sure if she sat there for minutes or hours or 
days, for this blackness was the solvent of time, holding seconds in a disordered suspension' (141). Passing her school, she finds herself in 'the looking-glass forest where names disappeared' (144). In Through the Looking-Glass, going through 'The Wood Where Things Have No Names' is the only way for Alice to get to her goal, the Eighth Square on the chess board where she can become Queen. While there, she forgets her own name, crying out, 'who am I?' Laura never forgets her name, and yet of course her journey is just as much a search for her own identity as Alice's. She will never reach the end until she knows who she is, as distinct from the shaping elements of her past, symbolised by the storybook characters and creatures from her childhood, 'all going in the opposite direction' (145).

A further parallel can be seen in the dangerous waters that both Alice and Laura encounter. Alice's changes in size cause her to become confused and frustrated. She starts to cry, inadvertently creating a pool of tears that becomes dangerous when she shrinks once more. Alice concludes that this must be a kind of punishment for her child-like display of emotion; surviving this watery trial then can perhaps be read as a kind of baptism or rebirth during which immature emotional behaviour is replaced by the development of adult selfsufficiency (albeit temporary in Alice's case). ${ }^{8}$ Similarly, Laura encounters rising water, which becomes dangerously high. In contrast with Alice, Laura is able to use the water for her own purposes, deliberately diving in to it when encroaching reality threatens to disturb her internal journey. Later she is able to direct the flow of water through a canal to symbolically fertilise and awaken a dormant part of herself (her witch self). Taking the link between water and symbolic rebirth to its full conclusion, Laura crawls through 'a wet, helical path'. Here, Mahy explicitly parallels Laura's journey with Alice's:

\footnotetext{
${ }^{8}$ See for example, William Empson's 'Alice in Wonderland: The Child as Swain' for a psycho-analytic reading of the pool of tears as amniotic fluid.
} 
It grew so tight she began to despair, for though the wand, like a rod divining spaces in solid rock, showed her a path, she was not sure she could follow it. Like Alice she did not think she would ever be small enough to reach the beautiful garden. "Even if my head did go through," she whispered, hearing the echo of the whisper from the adjacent rock, "it would be very little use without my shoulders". It suddenly occurred to her she was being born again and, as this thought formed, the helix took her as if it had come alive. She was being held and expelled, moved in a great vice, believing her intransigent head with its burden of thoughts, dreams, and memory must split open, and she came out somewhere into darkness. Reviving water continued to fall on her face (150-151).

Like Alice, Laura has survived the pool of tears. However, while for Alice the garden she enters afterwards is revealed as every bit as cruel and disturbed as the rest of Wonderland, for Laura the passage is a positive one. When Sorry suggests that he has rescued her from her ordeal, Laura rejects this, instead asserting 'I woke myself'. Coming to terms with this new adult identity means that Laura has in fact given birth to herself, transforming into the mature reflection staring back from through the looking-glass:

By candlelight she saw plainly that she was remade, had brought to life some sleeping part of herself, extending the forest in her head. She was no longer formed simply from warring Stephen and Kate, but, through the power of charged imagination, her own and other people's, had made herself into a new kind of creature (152).

To conclude my discussion of the significance of the Wonderland motif in The Changeover, I wish to return to my earlier assertion that both Carroll and Mahy use the power of words as a frame for their protagonists' transition into another world. As Lucie Armitt points out, Alice is considering the usefulness of books and reading just before she 
slips into Wonderland; dreaming thus becomes a form of creative writing where Alice creates a fictitious world for herself (28). Similarly, Alice creates her own passage into LookingGlass Land by telling a story: 'Let's pretend there's a way of getting through into it... Let's pretend the glass has got all soft like gauze, so that we can get through. Why, it's turned into a sort of mist now, I declare!' (181). In The Changeover, the kind of magic wielded by witches has its source in the imagination, and in the power of words. Laura's changeover world is drawn from her own imagination, mixed with literary memories and images, which points to the connection between magic, power and language. As Josephine Raburn notes, Laura's literary influences

progress from simple to complex as they parallel Laura's movement from childhood to maturity. She talks to Jacko in folktales, but when she speaks with other characters, she uses references to classics of children's literature. After the changeover, she refers to adult works [such as William Blake and Shakespeare] (30).

Indeed, we see the changed-over Laura taking the final developmental step from merely referring to adult works of literature to actually becoming a type of author herself. To defeat Carmody Braque, Laura must use words to give effect to her magic; as Sorry tells Laura '[y]ou do know what you want [the spell] to do. Make up the words!' (153). Creative forces are thus the means by which Laura takes control of her new-found personal power. This links Laura with Harry, protagonist in The Tricksters, who likewise begins and ends her journeys into a Wonderland-type other world through the desire to wield words. The power of imagination and the positioning of the female heroine as an author-creator is prominent in both, with Laura's power expressed through magic and Harry's through the writing of fiction.

The Tricksters, published closely after The Changeover, deals similarly with an adolescent female's search for identity, in this case for a more secure place within her family 
unit. Harry, at seventeen, is more actively seeking a change in identity than fourteen-year-old Laura. Harry's place as the middle child in the family has become restrictive, and she craves an adventure to break her out of the mould:

She was sick of feeling closed in by people above and people below, of being good old Harry, not wonderful Ariadne, for that was her real name. She was sick of being gratefully but carelessly praised for docility when she wanted to have a turn at being the difficult, brilliant one instead, and she longed to be overwhelmed by something so whirling and powerful she could never be expected to resist it (32-33).

As Harry chats with her younger siblings about what they might like as presents for Christmas, she tells them she would like a special kind of book:

“As you read my book you alter the world. You read Chapter One, look up from its pages and - hey presto - things have changed." "Like Alice in Wonderland?” asked Serena, interested. "Not that sort of change!" Harry said, peering down into the water again. "It would just be little changes to start with, and nothing would move while you watched it. But each time you looked up, things would have altered more and more. Things would get brighter and brighter, and the moon would come down, inch after inch, until it broke into a thousand little moons. Mirrors would begin to cry silver and leak out rainbows, and the glass people would come out searching for the one they belonged to. You'd look up from a page and see the reflections getting about, peering into people's faces, and when they found the right one they'd hug them, and from then on that person would be seen in their true beauty." (33-34). 
Harry envisions a book in which the roles of reader and writer are conflated by the reader's imagination causing an active re-writing of the outside world. With this passage, Mahy immediately places imagination and writing at the centre of the novel. Despite Harry's claim that her book would be different from Alice in Wonderland, her vision of mirrors leaking rainbows sounds Carrollian. To experience a Wonderland world would be an irresistible adventure; however, Harry makes it clear that she wants to be the active creator of the world, rather than a passive observer. In this way, Harry aligns herself with the more active version of Alice in Through the Looking-Glass, who deliberately envisions Looking-Glass Land, rather than the passive Alice who, in her dream, falls down the rabbit hole in Wonderland. Harry is tired of dreaming, and is ready to skip straight to Looking-Glass Land, creating her own world through the writing of fiction.

When Serena argues that there is no such book, Harry declares she will write it herself. With this secret wish verbalised, Harry begins the process of authoring her fantasy, blurring the boundaries between Wonderland and reality. Ending her conversation with her brother and sister, Harry then metaphorically passes through the looking-glass by slipping into the sea, 'the water smooth enough to form a mirror' (30). She swims down to the cave she knows lies beneath the surface, putting her hand into the cave to reassure herself that it isn't a bottomless hole, something she has done numerous times before. Things are different, however; this time she is secretly looking for a rabbit-hole that might offer access to another world. Linear space seems to become disturbed as Harry's hand finds 'an alien space there in the tunnel under Teddy Carnival's rock, so she was in one place, and somehow, her hand was in another' (36). ${ }^{9}$ It is suggested that the hand she touches through the tunnel belongs to the

\footnotetext{
${ }^{9}$ Anna Lawrence-Pietroni notes that linear time is also shattered by the appearance of ghosts; death is not the end (91). The Carnivals are also able to bring the past into the present, as when they reconfigure the hallway at Carnival's Hide to resemble what it looked like in Edwardian times. Meanwhile, Anna Smith argues that
} 
ghost of Teddy Carnival, an original occupant of Carnival's Hide who died under mysterious circumstances. Harry pulls her hand back in fright and bursts to the surface of the sea, where she bobs, finding herself 'believing that the space beyond the rock was the same space that existed behind the lines of print in her book, and she had but managed to reach through to it and had actually touched one of its inhabitants' (38).

Not only has Harry seen through into her own version of Looking-Glass Land and touched one of its fictional characters, she has also brought the fantasy world back through with her into reality. Soon after the cave episode, the three Carnival brothers appear on the scene, and Harry has the disquieting suspicion that they are somehow manifestations of characters from the lurid romance she is secretly writing; as 'Ovid [Carnival] looked rather like Prince Valery, and the enantiomorphs, Felix and Hadfield, exactly like the marvellous winged man, Belan' (95). In this way Harry differs from Alice, who writes herself into another world where she has the opportunity to become a Queen; Harry instead superimposes her fiction onto reality, as her words literally come to life. Rather than the fantasy of being Queen in an escapist world, Harry's fantasy is to use authorship to gain control over her own life. The manifestation of Felix enables her to experience her developing sexuality in a manner over which she can exert control, while the one-dimensional Hadfield and Ovid reflect Harry's aggression and frustration at being an invisible, middle child, and her desire to reveal the secret affair between Jack and Emma.

A key difference between Alice and Harry, that is, the level of interaction between the fantasy world and reality, is borne out by the very different endings of the two novels. Once Alice has become Queen at the end of Through the Looking-Glass, she rejects the

\footnotetext{
'although Mahy doesn't say this, [I imagine that] it is Harry's writing hand that gets trapped in the space beyond the cave' (51). I find this convincing because, after all, when Harry is writing her fantasy romance, she is in one place, and her 'magical writing hand', as an extension of her imagination, is in her fantasy world.
} 
constricting burden of adult responsibilities (represented by her crown, described as very heavy, and fitted tightly round her head [315]) and confusing etiquette that such a position entails, instead crying 'I can't stand this any longer' and shaking herself out of LookingGlass land back into reality. While Alice might have written herself into a fantasy of adulthood, ultimately it can't be sustained, since she undergoes no real emotional development. This argument is supported by Susan Sherer, who notes, 'for a narrative that thematizes motion, Alice's psychical growth remains disturbingly static' (1). Thus she remains childlike upon her return to reality, 'pratt[ling] on' to Dinah and the kitten, never engaging in any self-reflection and never resolving the alienation and boredom that caused her to take the journey into Looking-Glass land in the first place. Sherer argues that this lack of internal development arises from the 'scarcity of emotional connection, and even love' in Wonderland and Looking-Glass Land, suggesting that Alice's circular conversations with inscrutable characters such as Humpty Dumpty 'illustrate, at bottom, the hollowness of relationships in Alice's dreamworlds' (9). We may compare this with the ending of The Tricksters, where Harry accepts rather than rejects her own kind of coronation, becoming queen of the sea through symbolic marriage. Mahy emphasises the idea of unity in this passage; after her union with the ocean Harry goes on to have what Elliott Gose calls 'a strong unifying vision' (10) where the four traditional elements of earth, air, fire and water come together:

Harry took off her morning clothes and walked into the sea. Once in it, it flowed over her, warm and cool at once, if that were possible, more sensuous than Christobel's silk dressing-gown. [...] On the sand again, she turned almost instinctively, it seemed, and saw the sunrise. A little notch in the broken skyline filled up with fire, and Harry was filled with fire too. In the end she was possessed by the brute blood of 
the air so powerfully but so delicately it was like no possession she had ever imagined (329).

This vision of unity reinforces one of the novel's central themes, the intertwining of fantasy and reality. Mahy seems to be suggesting that Harry's ability to weave Wonderland into her reality has much greater power as a developmental and stabilising force than Alice's fantasy of two autonomous worlds that bear little relationship to each other.

I now turn to the theme of the carnivalesque (usually thought of as involving inversions, reversals, disorder, chaos and the appearance of a trickster figure) as seen in the Alice books and The Tricksters. Mark Hennelly, in his analysis of the Alice books as Bakhtian 'carnival tales' lists some of the carnivalesque elements found in Carroll's books:

... a dreamy descent underground, grotesquely gigantic and dwarfish carnality, a prodigious pool of bodily fluid, cartwheels and pratfalls, cornucopian helpings of food and drink, antic playgrounds, riddling language and name games, repeated nonsense (re)verses, various negative capabilities, mathematical miracles, voyages of discovery, cycles of crowning and uncrowning, not to mention meta-lists like the previous catalogue in this sentence (1).

As Phyllis Stowell has noted, Alice encounters several trickster characters during her journeys, including the Cheshire Cat (who is able to vanish and reappear at will, and transform from a cat with a smile to a smile without a cat, and who constantly uses paradoxical language) and Humpty Dumpty (also a master of language), who famously tells Alice: 'When I use a word, it means just what I choose it to mean - neither more nor less.' Mahy is clearly alluding to this tradition; through the very title, The Tricksters, she introduces the central figure of the Carnival tradition, the fool, or trickster, whose function is to 
temporarily invert order and suspend rules, so as to act either as a release valve, or as a catalyst for transformation. Mahy even names her trio of trickster figures Carnival:

"It means something like 'goodbye to flesh'," Hadfield volunteered. "People used to eat a lot to celebrate just before Lent. They used all their appetites excessively before attempting to exercise self-control - 'Carne levare' (that's 'a leaving off of meat'). 'Carne vale' - Carnival.”

“Don't try to be clever, dear, that's my job. In our family I'm the head, and Felix is the heart, and Hadfield's a simple predator." (Hadfield smiled lazily.) "If our name does mean 'goodbye to the flesh', don't we contradict it just by being here?" (87-88)

As Stowell (writing about Alice in Wonderland) points out, 'the mercurial Trickster is always present in the transformative journey, and his ultimate effect is positive; in fact, the presence of this ambivalent energy is crucial for change, and our discomfort with it is merely our discomfort with any new, foreign or un-understandable experience' (5). The Carnival brothers fulfil the function of trickster-guide for Harry, invading and inverting the order of an ordinary Christmas, and opening up space for her development. Despite Harry's feeling of unease about the brothers, Mahy suggests they are temporarily necessary for Harry's quest for authority. Having fulfilled their function, they literally disintegrate, leaving Harry as a changed person.

As with magic in The Changeover, the carnival element in The Tricksters is associated with words as a powerful force with the ability to bring about change. The tricksters' arrival is heralded by a 'procession of creatures' drawn in the sand at the sea's edge, which 'capered and clowned along on stick-like legs, turning whiskered faces to look at 
[Harry]. Humans, horses, cats and owls all wore the same crescent smile' (69-70). ${ }^{10}$ This procession of oddities is foreshadowed by the procession of scraps of poetry that inundate Harry's mind as she wakes up that morning. The Carnival brothers, (particularly Ovid) are tricky speakers, 'true Carnival performers, but tossing words, not balls and batons, through the air, juggling for a living' (88). The lesson Harry must learn from them is that language is a double-edged sword; words may help her write herself an identity, but they are also a destabilising force, as with the revelation of the uncomfortable truth about baby Tibby's parentage.

We see the carnivalesque aspect of the novel come to a head in one of the culminating chapters, significantly titled 'Breaking Free'. Here, the Hamilton family host a fancy dress Christmas party, a masquerade where guests can dress as their opposites - fools become wise, true beauty is exposed, and artifice is shown for what it is. The party is led by Ovid, the selfproclaimed 'King of Rainbows' and 'creator of the universe' (103), playing the part of the carnivalesque Lord of Misrule. Ovid creates Christobel's costume, painting her with makeup, 'her eyes outlined with kohl, shaded with gold, her lips blue, her hair sprayed into a stiff, glittering crest'. As he does so, Christobel grows 'less and less able to smile of her own accord' (240-1). As Ovid completes the costume, Harry comes to realise the falsity of Christobel's persona - her beauty is only external, and her vanity allows her to be dangerously manipulated by tricksters like Ovid:

She had become the marionette of [Ovid's] dreams, a toy of precious but lifeless treasure. [...] He kissed his own work of art, thought Harry, anxious to experience it by tasting and touching and smelling just what he had made, and she shivered and wondered if there was really a live sister left in the core of that beautiful puppet (241).

\footnotetext{
${ }^{10}$ A cat wearing a 'crescent smile' here surely suggests once more that trickster Cheshire cat.
} 
The carnival has allowed their positions to become inverted, as in contrast to Christobel's artificial beauty, Harry the 'ordinary' (237) has come into her own true beauty as a wielder of words:

Harry's fancy dress would have to be her true, astonishing self, inventor of beautiful winged demons, conqueror of the ravishing Hadfield, adversary of Ovid - the very girl who had tempted Felix under the furious blade of the lightening. So she did not want to dress as a witch or gypsy. She wore her black swimming suit and unicorn skirt and left it at that (237-8).

Walking as her 'true self' (237) amongst party-goers dressed in costume gives Harry a new sense of confidence. However, it is not until Felix points it out, that Harry realises that she is just as important in her younger sister Serena's eyes as Christobel is in hers. These two reversals open up an opportunity for self-actualisation as Harry realises she has 'found space for wild and sweeping games, magical acts with no one crowding around her' (254-255). Yet despite finding space for herself in this way, Harry remains constrained by her role of undemanding middle sister and silenced by the fact she is keeping the affair between Jack and Emma secret. Recognising her opportunity to display power over Christobel, who is unaware of the affair, and goaded by the Carnival brothers, Harry reveals the affair, shattering the illusion of family unity.

This family rupture is necessary but temporary; the release of the secret allows Harry and Christobel to relate to one another as adults rather than jealous or arrogant siblings. Ovid, Hadfield and Felix have, in Gose's words, brought 'the spirit of carnival license, an incentive to release inhibitions, to reveal repressed impulses of both love and anger' (Gose, 8). Once these impulses have been revealed, Harry finds she no longer has need of the tricksters and they dissolve, 'like a jigsaw-puzzle man falling apart' (295). As they disintegrate, so Harry 
consigns her childish romance book to the ashes of a beach bonfire. Although disruptive and sometimes disturbing, Mahy's tricksters, like Carroll's Cheshire cat, cause their heroine no lasting harm. Rather, the lasting change brought about is positive, allowing Harry to begin writing a new story of her own without resorting to the 'faulty story' (135) of submission to others.

To conclude, while there can be no doubt that Mahy has been influenced by Carroll with her constant references to Alice and the Wonderland motif, in fact her heroines bear little resemblance to Carroll's. Laura and Harry come to have an understanding of themselves and the world in a way that Alice never does, for Alice has very little internal life. Carroll does, at times, use his other worlds to project the psyche; however, it seems their main purpose is to reflect the absurd nature of the real world - his is an outward-looking view. Mahy's focus is different in that her mirrors and other worlds reveal what lies inside (and ahead of) Laura and Harry. Both Harry and Laura are able to relate their internal journeys to their outside worlds, having employed Wonderland as a licensed space in which to harness their creative energies, writing and magic. In this way, Mahy can be seen as countering Carroll, asserting that for the emerging heroine of the twentieth century, a self-contained Wonderland is no longer enough; rather it is the juxtaposition and integration of Wonderland with the awkward and sometimes dangerous reality of adolescence that enables identity formation. 


\section{Chapter Two}

\section{Imaginary Islands in Dangerous Spaces and Kaitangata Twitch}

If Carroll's Wonderland may be considered the quintessential 'other world' of Victorian children's literature, the island surely ranks a close second. Mahy demonstrates her awareness of the tradition in children's literature of the island as a fantasy space by alluding to the canonical island texts of Treasure Island and Peter and Wendy. In particular, Mahy hones in on the paradoxical nature of the island motif in the Victorian works, recognising the islands of Stevenson and Barrie as images of both heaven and hell, dream and nightmare. She uses this paradoxical island emblematically in Dangerous Spaces (1991) and Kaitangata Twitch (2005) to show the conflict felt by her young characters between wanting to carve out space for themselves, and fearing isolation from their own families. Mahy also draws on the literary tradition of the island operating as a symbol for the self, using this to explore the individuation and maturation process from child to adolescent.

The island as a literary setting or motif has a long and rich history, from Homer's Odyssey to Shakespeare's The Tempest and beyond. In terms of relevance for works read by children and adolescents, however, it all begins with Daniel Defoe's Robinson Crusoe (1719). While not originally written for children, Robinson Crusoe, in Diana Loxley's words,

... had by the end of the eighteenth century - before the establishment of a full-blown literature specifically for children - suddenly, miraculously, 'become' outstandingly popular with children. [Robinson Crusoe] now stand[s] at the forefront of a long tradition of children's literature. Robinson Crusoe is a work whose influence and impact is so pervasive as to be almost unthinkable (73). 
Robinson Crusoe was followed by a large number of imitations and reworkings, which have been loosely termed 'Robinsonnades'. This is a genre in which travellers are marooned on (or less frequently, seek out) a desert island, far from home, and must rely on their own resources to survive, during the course of which the castaway is obliged to 'subdue, bend and surmount the obstacles of nature to his own ends while at the same time maintaining (or gaining) reason and moral integrity' (Hebblethwaite, 26). Examples of these include Verne's The Mysterious Island (1875), Wyss's The Swiss Family Robinson (1800), Marryat's Masterman Ready (1841), Ballantyne's The Coral Island (1857), and of course, Robert Louis Stevenson's Treasure Island (1883), amongst many others more formulaic and derivative that have long since ceased to be read. An underlying theme of Victorian and Edwardian Robinsonnades (and other sub-genres of adventure stories for boys) is the imperialist drive of the time, replicated in the stories' repeated plots of occupation and possession of 'wild' and 'savage' island spaces. British castaways in Robinsonnades become 'monarchs of all they survey', entitling them to exploit both the natural riches of the land and subdue indigenous people, in the name of 'civilisation'.

Plenty of scholarly work has focused on the colonial aspect of island narratives. ${ }^{11}$ Although New Zealand is itself an island colony, my reading suggests that while Mahy sometimes flirts with exploring or subverting the colonial origins of the island narrative, overall she focuses on the island as a symbol for the internal psychology of the individual instead. This notion of the island as individual harmonises with Jung's concept of individuation, as William Blackburn points out in his discussion of Treasure Island (9). ${ }^{12}$ While other novels such as The Haunting and Aliens in the Family clearly show Mahy's

\footnotetext{
${ }^{11}$ See, for example, Loxley's Problematic Shores: The Literature of Islands, or Empire Islands: Castaways, Cannibals, and Fantasies of Conquest by Rebecca Weaver-Hightower .

${ }^{12}$ See Chapter Six of Jung's Memories, Dreams and Reflections.
} 
interest in New Zealand's colonial past, of the novels where islands figure prominently, only Kaitangata Twitch shows a particular concern about the imperial colonisation of islands, with the contemporary 'colonisation' of Kaitangata by property developer Marriott Carswell.

Leaving this aspect of Kaitangata Twitch aside, it would seem that rather than writing back to the colonial underpinnings of island narratives, Mahy picks up on another major theme developed in these texts; that is, the literary island as a space for self-development and maturation of the child character. I will argue that Treasure Island and Peter and Wendy, as well-known island narratives with child protagonists, provide Mahy with a rich resource to explore this idea in her own work. In Treasure Island we see the island as a little world, in which the child character may practise adult agency, vicariously enjoyed by the reader. Positively speaking, this island is quasi-paradisal, free. But it is also a place of disillusionment. In Peter and Wendy, the island of Neverland serves the same positive purpose, emphasized by its explicitly fantastical nature. But Neverland too is ambiguous, being suggestive of stunted development for those who wish to remain there indefinitely.

I will first discuss the ambiguities found in Treasure Island and Peter and Wendy before returning to Mahy's work. Treasure Island is a classic example of the island narrative written for children, which by now had moved away from the adult hero seen in Robinson Crusoe to child heroes more easily identifiable with by the child reader. For Jim Hawkins, protagonist of Treasure Island, the island represents the dream of adventure, where play becomes blurred with reality. It is an in-between place where Jim can pick the choicest parts of being an adult - physical strength, authority, action - while at the same time rejecting the mundane responsibilities of finding a mate, raising a family, paying taxes. Stevenson's island is appealing because although it is a place that allows Jim to contend on an equal footing with the adults, sometimes even besting them, it is also, by topographical definition, a place of 
limited boundaries, implying that the adventure is merely temporary, and therefore less terrifying. Robinson Crusoe shows us that an island is the perfect place over which to exert human control; Treasure Island adapts this theme by positing the island as a place where Jim, a boy, can take control over situations where he would have none on the mainland. The island, conceived of by Stevenson as the opposite to the domestic sphere, is established as a carnivalesque space where the usual social conventions and power relationships no longer apply. As Loxley notes, the hierarchal roles on the mainland become completely inverted:

the Squire [...] displaced from a context in which his title bears meaning, gradually recedes from a central position to the extent that he eventually plays no part whatsoever; the Doctor, the supreme voice of reason throughout, assumes, by contrast, a status and authority disproportionate to his original position; and of course, the lowly cabin-boy emerges to the fore as the fiction's perfected dream-hero, the initiator, manipulator and controller of the action (151).

On the mainland, Jim is stymied by fear and helplessness when faced with pirates. Even though the pirate Pew is blind, he is able to use his 'voice so cruel, cold and ugly' (27) to frighten Jim into obedience. In contrast, on the island Jim can overthrow another pirate, Israel Hands, on his own with relative ease. This and other examples of Jim triumphing over adults indicate that the island represents a place where wish-fulfilment and selftransformation can occur, particularly the dream of authority: over others, the land, and by extension, oneself. As a closed space over which an individual can exert control, the island can then be read as 'an image of the fully integrated self' (Blackburn, 9), or the dream that 
one has when searching for a sense of self. ${ }^{13}$ The island as a potential dreamscape is overtly pointed to by Stevenson, as the island features prominently in Jim's daydreams:

I approached that island in fancy, from every possible direction; I explored every acre of its surface; I climbed a thousand times to that tall hill they call the Spyglass, and from the top enjoyed the most wonderful and changing prospects (59).

A double transformation occurs here. While en route to the island, Jim starts to develop into the 'controller of the action' role that he desires; however, by the end of the novel he also becomes conscious that that this dream is not as charming as it sounds, and that with adult power comes adult responsibilities, including participation in the adult economy. The reality of the island, with its 'peculiar stagnant smell', 'sodden leaves and rotten tree trunks' and the landscape's 'poisonous brightness' (111-112) is in contrast to his daydream. The island, then, is a catalyst for Jim's growing up. This darker side of the island suggests the painful realisations that Jim comes to; that in contrast to the polarised boyhood ideas of 'goodness' and 'badness', adult morality is much more ambiguous. As Hebblethwaite puts it, 'that neither the 'good' is rewarded nor the 'bad' punished in the novel testifies to the moral ambivalence of the world and the inadequacy of a bipolar vision' (31). Therefore, the multiple and contradictory images of the 'real' island mirror the dual functions of the symbolic island: it is both a dream place where the dissolution of hierarchy frees Jim to take on aspects of adulthood and authority, and a nightmarish place in which the 'bright certainties of his childhood' are 'corroded' (Blackburn, 11) by the realisation that in order to be an adult there is a price to pay. In other words, to become a man, Jim must forgo his childhood

\footnotetext{
${ }^{13}$ It should be noted here that, of course, it is not uniquely islands where the fulfilment of the (young) person's wish for control is established - new frontiers such as the New World, the Wild West, and more recently, space - can also provide the setting for this to occur. However, it cannot be denied that the island provides a perfect image for a realistic yet escapist place where the natural order is removed or inverted and a figure for the self, floating alone on an unknowable sea.
} 
dreams and formulate a new understanding of the real world. Furthermore, as critics such as Mary Shine Thompson have noted, Jim's maturity and reintegration into the status quo of authority, accumulation of wealth and progress is not without its problems; his unresolved psychological anxieties are intimated by the nightmares the older Jim Hawkins continues to have of 'that accursed island' (16-17).

The connection between the psyche and the island is even more explicit in Peter and Wendy. Barrie takes Stevenson's description of Jim day-dreaming the Treasure Island from the map and upends it by envisioning a child's mind as a map of an ever-changing island:

I don't know whether you have ever seen a map of a person's mind. [...] There are zigzag lines on it ... and these are probably roads in the island; for the Neverland is always more or less an island, with astonishing splashes of colour here and there, and coral reefs and rakish-looking craft in the offing, and savages and lonely lairs [...] (6).

Moreover, the island visions of Barrie's characters 'vary a great deal' (7) from individual to individual, mirroring their own hopes and anxieties. The psychic map of Neverland described above has fantasy elements such as mermaids and fairies, but also mundane things like one's 'first day at school' and 'verbs that take the dative'. These mundane elements are described by Barrie figuratively as 'another map showing through' (7), suggesting that the island dream represents both home concerns and a desire for escapism (that is, escape from home, but not too far). As with Treasure Island, Neverland provides a space for the Darling children to have adventures and to assert themselves in ways they are unable to at home. Yet, as Anna Bogen argues, 'the Neverland functions as a training ground for the young characterised less by the dangers and pleasures of the desert island than by a haunting resemblance to real life, in which adventures remain consistently imitative of domestic realities' (55). In other words, Barrie envisions the island as a map (or reflection) of the 
psyche, so when the Darling children embark on their journey it is in pursuit of wishfulfilment, albeit where their wishes (particularly Wendy's) reflect in part the adult personas they will be expected to take up not long after their return to London.

Then there is Peter, for whom the island represents an arrested stage of development. Barrie acknowledges the sense of loss that growing up entails with the well-known passage: 'on these magic shores, children at play are forever beaching their coracles. We too have been there; we can still hear the sound of the surf, though we shall land no more' (7). He also, however, shows us the consequences of Peter remaining on the island. Peter deliberately isolates himself from relationships and the domestic sphere for fear of having his childish freedom removed, causing him to be 'heartless' and unable to conceive of love. His inability to remember may spare him the pain of consciously missing those who have left Neverland, but his unconscious knows what he is missing, for Peter has bad dreams that are 'more painful than the dreams of other boys', from which 'for hours he could not be separated [...], though he wailed piteously in them' (142). ${ }^{14}$ Like Treasure Island, Neverland has a double edge; while it represents independence, to remain there too long is to render the island a prison in which the desire for space and freedom dangerously outweighs the desire for connectedness and empathy for others.

Margaret Mahy is fully aware of the broad tradition of island narratives within children's literature. This is most evident from Dangerous Spaces, and Kaitangata Twitch. As we have seen in Treasure Island and Peter and Wendy, the island can represent both escape and imprisonment. The same kind of double-edged island is found in Dangerous Spaces; in fact the island is one of the 'dangerous spaces' of the novel's title. Protagonist

\footnotetext{
${ }^{14}$ It is interesting to note here that Jim perhaps has bad dreams because his childhood innocence has been lost, while Peter does because he unconsciously recognises that childhood innocence cannot be perpetually retained without consequence.
} 
Anthea dreams of visiting the island as an escape, yet this fantasy of solitude and space becomes a nightmare as it threatens to prevent Anthea's return to the real world. In Dangerous Spaces, the island is not a place that is ever reached - the novel's climax is not during adventures on the island, but rather when Anthea rescues herself (with Flora's help) from the island's lure. Mahy suggests that for Anthea, psychological development and maturation occur when she denies the corrupted island fantasy of isolation, inverting the Robinsonnade theme of the island as a licensed space for growth.

Anthea has been recently orphaned, her parents lost at sea after a yachting accident. She is devastated by grief and the inner fear that her parents have 'just pretended to drown and secretly swum off somewhere, away from me' (97). Furthermore, the noise and mess of her new circumstances living on a farm with her cousin Flora Wakefield threaten to overwhelm her. Anthea's distress begins to manifest itself in her dreams, where her unconscious envisions an island where her parents might be still alive. This dream island reflects the real island in the harbour near the Wakefields' house, which is 'shaped like an ancient dragon dreaming under the sky' (9). The dragon image evokes the island in Treasure Island, also described as resembling a dragon: 'It was about nine miles long and five across, shaped, you might say, like a fat dragon standing up...' (Stevenson, 53).

Treasure Island sets up a progression from island 'sea dream' to physical island; that is, Jim dreams of the island via the medium of the treasure map, before reaching it in reality. In Dangerous Spaces this pattern is reversed. Anthea is unable to visit the physical island, the suggestion being that the crowded reality of her home life is a barrier to this:

There was plenty of space out there [on the harbour island]. But between the house and the harbour lay the verandah, and when she glanced through the glass doors, she saw the verandah was already crowded (9). 
Instead she travels towards the island within the dreamscape world of Viridian. Viridian is not itself an island, but rather a landscape centred on an island which is surrounded by an inland sea. Here, as with Stevenson and Barrie's islands, the dream island Mahy creates reflects Anthea's psychological state - her hidden desire to regain the solitude she is used to, mingled with the desire to reunite with her dead parents.

Feeling increasingly marginalised in Flora's house, as if she has been 'squashed by all the energy around her into a paper doll with a polite smile' (8), Anthea purposely delves deeper into her dreamscape in an attempt to carve out a protective niche for herself. By now, the line between the real world and imaginary Viridian is becoming increasingly blurred injuries incurred during her dreams are still there when Anthea wakes up, suggesting that if Anthea achieves her aim of reaching the island and reuniting with her parents in Viridian, she will also die in real life. The landscape of Viridian is seductive for Anthea in its secret spaciousness; it is 'something of her own in a house where there was so little space for her, so little space that everything private was precious and had to be guarded' (79). However, as suggested by the novel's title, the space that Anthea seeks is more dangerous than she realises, as at the culmination of her journey into Viridian lies the island, housing 'the hole in the middle of the zero' (76) - space indeed, but not space that can be enjoyed, for it is the negative black hole of death. By associating the island with nothingness and death, Mahy implies that Anthea's deliberate retreat into fantasy is potentially suicidal.

I turn now to considering the way in which Mahy portrays the island in paradoxical terms, drawing on parallels between Dangerous Spaces and the novels by Stevenson and Barrie. Like Jim's, Anthea's island is multi-faceted. At first, she imagines the classic island paradise, fantasising that 'her mother and father might be found again, shipwrecked on an island so small that no-one had ever discovered it before. They would be golden-brown and 
slender, able to swim like fish...' (13). This island image gives Anthea some comfort, but it also puts her in denial of their deaths, preventing Anthea from properly grieving. Furthermore, the fantasy isolates her from bonding with her new foster family. Anthea explores the house rather than playing with her cousin Flora; as she does so she discovers a stereoscope, an old-fashioned picture viewer that used to belong to her great-uncle Henry, who died as a child. Packed with the stereoscope, there are a series of picture cards, which function like the maps in Treasure Island and Peter and Wendy to evoke island dreams for the protagonists. Viewing the picture of the real island through the stereoscope triggers another island fantasy for Anthea, that of the island as a place of refuge:

Anthea, whose pulse had quickened at the sight of its empty beaches, imagined pulling a dinghy up on to the sand; imagined searching for shells, staring at the sea and lighting a campfire before setting out into the unexplored interior, and all in wonderful silence and solitude (21).

This image is complicated however by a threatening feeling that Anthea conveniently ignores. Contrary to Anthea's fantasy island, the real island is described in monstrous terms, 'straggled and hunched like a dragon hiding itself in the sea', while the water surrounding it has 'a dangerous look' as it 'eat[s] itself into a lacy pattern at the foot of the cliff' (21). Like Stevenson, Mahy emphasises the island's ambiguous nature; it is 'bland, but sinister, as well' (21).

In fact, it becomes clear that the island in Dangerous Spaces is associated with death, just as Neverland is in Peter and Wendy. In both novels, then, the desert/paradise island binary can also be read as representing heaven and hell. For Anthea, the island image is inextricably bound up with the death of her parents; both literally, since they died during a boating accident, and through her fantasies as outlined above. The binary of heaven and hell 
is also present in Peter and Wendy, where Neverland and Peter are associated several times with death. Peter wears clothes made from 'skeleton leaves' and his statement 'to die would be an awfully big adventure' (109) is linked to the novel's concern with growing up - Peter would rather die than become an adult and give up his youthful adventures. ${ }^{15}$ Moreover, Peter is a murderer several times over, and a callous one at that; "I forget [the pirates] after I kill them," (192) he tells Wendy. This sits uncomfortably with the picture painted of Peter by Mrs Darling at the opening of the novel that 'when children died he went part of the way with them, so that they should not be frightened' (8). All of this suggests that Neverland is in fact an island of the dead, populated by ghosts, an implication which is never fully resolved in Barrie's novel.

To illustrate this contradiction, Neverland seems heavenly to the Darling children (at least at first). It is, however, a heaven out of reach of adults:

... if you shut your eyes and are a lucky [adult] you may see at times a shapeless pool of lovely pale colours suspended in the darkness; then if you squeeze your eyes tighter, the pool begins to take shape and the colours become so vivid that with another squeeze they must go on fire. But just before they go on fire you see the lagoon. This is the nearest you ever get to it on the mainland, just one heavenly moment (93).

As William Blackburn argues, this passage places Neverland in the context of 'the lost heavenly land behind the wall of flame' as 'Barrie's subtle invocation of the Garden of Eden

\footnotetext{
${ }^{15}$ Interestingly, a stage direction at the end of Act V of the play version of Peter Pan; "If he could get the hang of the thing, his cry might become 'To live would be an awfully big adventure!' but he can never quite get the hang of it" suggests in fact that Peter's obsession with youth prevents him from truly living life. As Kathleen Blake argues, 'Barrie was aware of and more than hints at the sterility, and even morbidity, of the ideal of perpetual youth' (177).
} 
guarded by the angel with the sword of fire (Gen. 3.24) reminds us that childhood is indeed a type of lost paradise' (11). Yet it is only heavenly for those who are able to leave, or rather, the memory of Neverland seems heavenly to those who have left. Those who remain, and especially Peter, are trapped in a never-ending purgatory of death and forgetting, where the hollowness and morbidity of eternal youth is emblematised by absurdities such as the continual battle between the pirates, the redskins and the Lost Boys where no-one ever wins, or the children existing on make-believe food.

In a similar fashion, while Anthea's island fantasy at first seems a heavenly respite from the chaos at the Wakefields', it becomes more hellish the closer she gets to the island within the dreamscape, Viridian. In searching for an island space in which she can be reunited with her lost parents, Anthea is actually contemplating the seductive possibility of her own death:

'What is the island?' she asked, wondering why she had never asked before. [...]

'It has lots of names,' Griff replied in a small, reluctant voice. 'Mostly people don't talk about it, but everyone has to go there in the end' (66).

Rather than seeking to prolong her childhood, as Peter Pan does on Neverland, Anthea no longer sees any value in her life and longs for escape. She is encouraged by the ghost of her great-uncle Henry, creator of the fantasy world she has entered. Henry (known in Viridian as his fantasy persona, Griff) is trapped in there and has been waiting for someone to help him reach the island (and finally die) as he is too scared to go alone. Griff and Anthea share a bond in searching for space:

'I think I came because there's plenty of room here,' Anthea explained. 'It's very crowded where I come from.' 
'It was crowded for me before I came here,' the boy said. 'Leo took up all the space there was.'

'I have a cousin who takes up all the space, too,' Anthea replied sympathetically, half guessing who Leo might be (53).

Together they travel towards the island, slowly at first, then with an increasing sense of urgency. While this is happening during Anthea's dreams, in her waking life she is beginning to forge genuine relationships with Flora and Molly (Flora's mother and Anthea's aunt and foster-mother), thanks to Molly's deliberate avoidance of taking on the 'wicked stepmother' role. Molly comforts Anthea, assuring her that her parents' death had nothing to do with her and together the three of them work to plant a new forest of trees, which helps Anthea begin to feel like there is space for her in the new family:

More than two hours had gone by [planting trees], and she had not once longed for the road and Griff. All that time she had been entertained, even happy. It seemed to her then that she must have somehow carried some of the space of Viridian back into the everyday world with her, but kept it in her own head, behind her eyes. Or perhaps there had always been a magical space there which she had somehow looked over or looked through until now (62).

It is at this juncture that Anthea decides she no longer needs to escape reality: “"Perhaps I'm getting tired of Viridian," she said, surprising herself. "Perhaps I don't want to dream anymore"' (69). However, the wheels are already set in motion, and she becomes trapped in Viridian, inexorably drawn towards the island of death, lead on by Griff/Henry. "I've got you now," Griff tells Anthea triumphantly, "We're going on, and this time we won't stop until we get there" (99). 
To escape the deadly fantasy, Anthea must shrug off the seductive promise of isolation that keeps her in thrall to the island and abandon the fantasy of her parents; instead she must forge relationships with her new family to remain in reality. Here, Mahy seems to be suggesting that strong familial relationships are the key to growing up, and that isolation (even in the guise of space and solitude) is dangerous rather than developmental. Furthermore, the acceptance of reality and denial of fantasy also seems to be part of Mahy's message, an interesting stance from an author whose books are rarely without fantasy elements. Here, Mahy seems to be aligned with Barrie in that an over-reliance on fantasy is shown to be childish and hollow, even detrimental, while a focus on the real indicates maturity. The island fantasy may be a comforting idea for Anthea and for the Darling children temporarily; however it is in turning away from the island and back towards the family that represents the developmental experience for the young characters in each novel.

Perhaps there is a twinge of regret at having to give up an attractive vision (an eternal childhood, an island of respite, a painless suicide); this can be seen when Anthea and Flora take their last look at the island (the real island) and bid farewell to the ghosts of Anthea's parents, and Griff/Henry and Leo:

Though the sun had set, a rim of light lingered around the hill behind them, reflected out by the mouth of the harbour. The island looked closer and blacker than usual. Suddenly Flora caught Anthea's arm.

"Look!" she cried. "A fire."

Someone had indeed lit a little fire on the beach of the island. They could see the flames leaping up and, black against the flames, figures running backwards and forwards piling on more drift-wood. 
"Is it [Leo and Griff]?" asked Anthea. "Is it a sign?"

"There's more than two of them," Flora said, peering out toward the island at the figures, dancing in and out of the distant glow. "I wish we were there." (130)

However, in the end, the limitations of the island as a fantasy space are made clear. Once Anthea feels loved in her new family, she no longer has need of the fantasy as an emotional crutch and so the island fades away:

So they went home, side by side this time, picking their way over the peninsula, which seemed to sigh around them as if either the evening or the land were breathing contentedly. Behind them, across the dark, murmuring sea, the fire and its reflection died down to nothing. The shapes - the dancing ghosts that had moved around it became part of the good darkness, and the whole island vanished at last, an indistinguishable part of the night (131).

It is important to note here that for Griff/Henry and Leo/Lionel, the island is their proper destination as they are already dead. Mahy contrasts the natural deaths of Henry and Lionel with the unnaturalness of Anthea's potential suicide, suggesting that death should neither be feared nor deliberately sought, but rather, accepted as a natural inevitability for those who have reached the end of their allotted time. In parallel to this, the ghosts of Leo and Griff must leave behind their fantasies of remaining in the world of the living (exhibited by Griff through his Viridian dream and Leo through his haunting of the family house). As Anthea must accept her parents' death, Leo and Griff must accept their own. Once they do so, the island reverts back to its paradisiacal aspect for Leo and Griff, while for Anthea it loses both its appeal and danger and fades away. 
I have argued so far that Treasure Island and Peter and Wendy paved the way for Mahy to portray the island as a paradoxical fantasy space. Through the binaries of dream/nightmare and heaven/hell, the Dangerous Spaces shows both the pleasures and the potential dangers of the desire for solitude. Since Anthea never actually reaches her dream island, it does not function as a space for licensed development in the same way that islands do in the other narratives; although it does feature as a fantasy space for wish fulfilment, as with the source texts. Mahy complicates this, however, by showing that Anthea's wish (although superficially attractive) is a dangerous one, which would prevent the cycle of development and reintegration rather than enable it. The sense of loss of childhood problematically inscribed in Barrie's vision of Neverland is not really present in Dangerous Spaces. Rather, Mahy draws from his work themes about the dangers of not growing up and reintegrating with society; that is, Peter and Wendy shows us that the real growth happens in realising the island fantasy has to be left behind (which Peter is unable to do). Griff is a Peter Pan-like figure in his desire to remain in a child-like state while waiting for his brother. He denies death in the same way that Peter denies growing up. In effect, then, Mahy makes explicit the connection between remaining in a state of childish fantasy and dying.

One of Mahy's more recent novels, Kaitangata Twitch, is likewise concerned with the developing maturity of its young protagonist, Meredith. Once more the lead character desires the space and solitude found on an island. The treatment of the island is somewhat different in Kaitangata Twitch. Environmental and political themes are much more strongly to the fore as the geographical island of Kaitangata comes under threat from property developer Marriott Carswell. An aspect which is explored much more comprehensively in Kaitangata Twitch, then, is the connectedness between the land and its occupants (both historical and 
contemporary), particularly the island itself. In this way, the novel touches on the colonial implications of island narratives, which Dangerous Spaces does not deal with.

Unlike the island in Dangerous Spaces, Kaitangata is easily accessible to Meredith as a place of escape. The accessibility of the island, however, is also what partially mars it for Meredith, for while she can easily escape to the island by canoe, she is also quickly followed by her brother and sister. Kaitangata's proximity to the mainland is also what puts it under threat, as Marriott Carswell buys it with the intention of turning the island into a holiday hideaway for the rich: 'There must be a few millionaires out there who'd love to own a place on an island' (45). Mahy thus establishes a parallel between Meredith and Kaitangata, since each are threatened by potential invasion - Meredith's personal space is invaded, while Kaitangata is threatened by development.

Since Meredith considers herself to be a loner, she has a particular affinity with the island. This relationship is both physical and spiritual. As with Anthea in Dangerous Spaces, the island begins to manifest itself in Meredith's dreams. In both novels, the connection to the island is formed largely because of a desire for personal space. For Meredith, Kaitangata is 'her favourite lonely place in the entire world' (31); the island represents a place where she can be alone from her noisy family and enter contemplative solitude. As the purity of the island as a place of escape is eroded by her invading siblings, Meredith increasingly travels to the dreamscape island instead.

Mahy also draws a connection between Meredith's talent for music and her island dreams. Music is an important means of expression for Meredith, and a way to differentiate herself from her family and align herself with something more mystical: 'Indeed, it sometimes seemed to Meredith that her dreaming and her music melted into each other, one making the other stronger' (17). Like Harry in The Tricksters, Meredith daydreams of being 
an enchantress, however, her tool of power is not writing but music. This is a power that Mahy associates with the prehistoric earth - it is suggested that music (played by someone suitable) may be able to calm the troubled landscape of Kaitangata, which is prone to earthquakes. Meredith's great-uncle Lee Kaa is another family musician and dreamer who shares Meredith's connection with the island. When Meredith has had enough of her family debating about environmental issues, she goes to down to the beach, 'certain that this was a time when Lee Kaa would have finished his gardening and that he too would be stealing time from everyday life, to sit on the log on the foreshore and play his saxophone' (66). Meredith's usual instrument is the flute; her time playing the saxophone with Lee Kaa represents her ability to do something different, 'somehow off to the side' (22) of family life. Interestingly, music is a way for Meredith to make space for herself, rather than to connect with others:

If she took official [saxophone] lessons she would probably have to follow the notes written in lines on a page of music. She would have to put up with Rufus banging on her door and hooting. There was a lot to be said for playing every now and then in the evening with Lee Kaa as her teacher and her only listener... unless you counted Kaitangata, that island lying like a secret, strange tear on the moonlit cheek of the harbour (22). ${ }^{16}$

As well as being her music teacher, Lee Kaa functions as Meredith's spiritual guide. He too feels the connection to the island, and warns her that it may not be as benign as it seems, explaining the island's history as a site for Ngai Tahu human sacrifice and cannibalism. When Meredith tells him she feels as though the island is talking to her, that

\footnotetext{
${ }^{16}$ This is similar to Harry in The Tricksters, whose writing is mainly an expressive outlet for herself, rather than a medium of communication.
} 
she suspects somehow Marriott Carswell's plans for building on the island have caused it to 'wake up', he confirms her as the island's protector. 'First there was me, and now there's you,' Lee tells Meredith, 'Maybe when that little old island wakes it needs someone to talk to' (74-75). As if to underline the link between the island, dreams and music, Lee gives Meredith a conch shell. When she plays, a 'curious sound came out of it - not the pure and golden note of the saxophone but a sound that seemed to struggle into the world through sand and moss' (68). The description of the sound suggests a powerful connection between music and the ancient earth that Meredith may be able to use to pacify the troubled Kaitangata:

“.. there's always the sound, coming and going. Yeah! That sound might be enough." Then, very deliberately, he looked past her [towards the island]. Meredith turned. The beach was empty. "Plays a sort of lullaby, perhaps," Lee said. "It's hard to get some babies to sleep" (68).

As with all the islands discussed so far, Kaitangata has dual aspects of dream and nightmare; it is a place of danger as well as a place of refuge that is worth preserving. The island's topography is described repeatedly as a mixture of both dark and light: 'though the rounded western end of the island was blanketed by early-morning fog, the sharp eastern end was bright with light' (4), and later 'the fist of the island, both dark and bright, struck upwards into the shiny air' (145). The island's double nature is further emphasised by the image of its reflection as dream-island:

The water shone as if the softly stirring morning air had carefully polished it. The hills of the bay and the knotted hump of Kaitangata rose out of that glass but also hung, reflected, below it. Perhaps the island of her dreaming was that other, lookingglass island (32). 
Clearly, the iconic images of looking-glass land and the island are associated here, suggesting that Mahy uses both Wonderland and the island as archetypes of the self to represent psychic development. As in Dangerous Spaces, Mahy makes explicit the link between the real island and the dream island, which serves to underline the idea of the island as a figure for the self. The island is a dream: 'directly in front of [Meredith], the island, half dream, half sea-animal, basked and waited', and dreamers are islands: 'Like Meredith, Lee Kaa liked to be on his own sometimes. Dreamers do, thought Meredith. Dreams branch out when you're alone, and dreamers are all islands, really' (181).

The island takes on human characteristics (hands, eyes and a mouth) in Meredith's dream vision. These features seem to represent the power to execute one's own will, to see reality and to speak for oneself, desires voiced by Meredith and her siblings. Yet when Meredith comes across each feature on the island, it is terrifying, suggesting that authority should not be taken for granted. The hand image shows the island as both a powerful 'warrior fist of rock', able to protect itself, and bloodthirsty, taking an innocent child as a victim - 'the blood trickling down from between the rocky knuckles was being squeezed from a lost child, secretly crushed for fifty years by the island's clenching fingers' $(61) .{ }^{17}$ Climbing on Kaitangata's hill, Meredith feels able to see more clearly, 'free under a wide sky. Meredith suddenly felt she had become God's eye' (39), yet Kaitangata's own eye looks into the darkness rather than the light:

Then the cliff opened a great eye and looked at her. The eye had no white to it. Its iris was dark and glittering with grains of embedded quartz, but its pupil was a black

\footnotetext{
${ }^{17}$ The 'lost child' referred to here relates to Shelly Gentry, a young girl who went missing on the island 50 years before. Shelly's ghost appears in Meredith's dream journeys to Kaitangata, and it is suggested that she was crushed by the island as a warning to her parents, who were planning to build a boarding house for holiday makers on the island.
} 
space, greedily sucking light from the surfaces of sea and sand, so that as light fell into it, an accelerating twilight seemed to surge around her [...] The pupil now became a pit into which everything must fall - and somehow she was not longer looking up towards it, but down into it. Meredith let out a cry. Too late! She was already falling into that circle of nothing, and somewhere behind her the eye was closing its lid. Darkness rushed into her open mouth, down her throat, into her lungs and stomach, up through her nose and into her brain. She was throttling on darkness, dying there beneath the surface of Kaitangata. She was becoming part of its inner night (93).

The phrase 'circle of nothing' in this passage brings to mind the description of the island in Dangerous Spaces as 'the hole in the middle of the zero' (79); both islands are closely connected with death. Kaitangata's mouth too, is deadly, swallowing Carswell whole in Meredith's dreamscape after she has 'called' him to the island, using a strange, 'sandy, gravelly voice that sounded as if it sifted out into the world through moss and fern roots' (146). The idea of being able to wield the voice of a powerful enchantress is exhilarating for Meredith, yet its power is frightening too:

'I called him and he came. And the island ate him.' Somewhere behind her ribs, her stomach muscles tightened and heaved. It was as if the Kaitangata twitch had actually become part of her. Meredith looked away, struggling and clenching her teeth. She felt torn between fear of Kaitangata and fear of herself because of what she might have done. Marriott Carswell might have been a villain, but she did not want to be the one who had lured him into the dreadful mouth of Kaitangata (163-164).

The troubling nature of the island's anthropomorphic features seems to echo Meredith's anxiety about her own changing body, other changes brought about by growing up, and more broadly, the changing landscape of the bay, brought on by human progress. Meredith's worst 
nightmares seem to happen when she is most anxious about these changes; she is torn between resisting change (both for Kaitangata and for herself) and the realisation that change is inevitable. Like so many of Mahy's heroines, Meredith is poised on the cusp of adolescence, 'balancing gingerly on some pitted ridge of volcanic stone, confused at being two different people in one and the same moment' (122). Meredith's brother draws attention to his sister's physical development, to her embarrassment:

“Merry's getting shy," Rufus said one morning at breakfast, "it's because she's getting - you know!” He sketched two curves in front of his own thin chest. Meredith felt her face grow suddenly hot (124).

This is echoed by a description of the changing shape of the land three pages later, implying the connection between the Meredith and the landscape: 'The new roads curled over the rounded slopes like purposeful worms, writhing across the land and eating it into a different shape' (127). The connection between her body and the island is underscored by Meredith's dreams of the island awakening, reflecting an anxiety with the 'awakening' of her adult body.

A connection between island landscapes (or other unknown territory) and the human body is often made in colonial representations of island narratives; however it is usually the male castaway that is able to control the feminised landscape. ${ }^{18}$ In this novel, we see the reverse: the feminine landscape of Kaitangata (with its association with Meredith's body) consumes and subdues the male would-be coloniser, suggesting that Mahy is subverting the traditional vision of superior masculinity implicit within older island stories, replacing it with an emphasis on natural, feminine power. However, as can also be seen in The Changeover, when Laura considers but rejects the idea of using her new powers of witchcraft to cruelly toy

\footnotetext{
${ }^{18}$ See, for example, Loxley's discussion of 'the metaphor of women as territory' in Verne's Mysterious Islands, (53-57), or Magali Compan's “'Cette terre qui me ressemble": Re-writing the Island, Re-writing the Self in Ananda Devi's Pagli'.
} 
with Carmody Braque, Mahy simultaneously sounds a warning about the responsibilities that are coupled with feminine power. Meredith's trepidation about her new-found authoritative voice shows that her island ordeal has taught her that authority over others must be used wisely.

After awakening from her nightmare vision, Meredith is comforted by Lee Kaa in his role as guide, advising her about the necessity of change:

'It's the way things are,' he said. 'You already know that. Everything gives up one shape, sooner or later, and takes on another. Once you get used to the idea, it seems halfway beautiful. Well, it does to me. The game of changes I call it, and at my time of life I'm edging towards a big change of life myself.' (169)

Meredith's growth experience comes from accepting that change (growing up, development of the land) is inevitable, but that it should never be forced or done without thought, lest one end up like Marriott Carswell. The key is to be found in developing an understanding of the land, and stronger connections to family, rather than self-imposed isolation:

Meredith was being exclaimed over, hugged, kissed, warmed and given midnight treats, an island no longer, but part of her family, as she always had been, and always would be, for in the game of changes, there were a few happy things that would never really change (169).

Using this new-found knowledge, Meredith is able to transform both herself and the island; aided by her 'melancholy, mossy song' which 'somehow echoed back into itself as it sang out into the world' (177). Her song briefly awakens once more the spirit of the island. "I don't want to change you," (180) Meredith shouts aloud as she feels something watching her. Like Meredith herself, however, the island does change, 'in its own way and in its own time' (180). 
Mahy seems to be suggesting that it is the freedom to not have change forced upon you, which is in fact, a catalyst for change, and that all this is positive:

Accepting that new road, even though it was signalling great alterations in the world of her childhood, made her feel somehow older and wiser. Maybe this is my first day of being grown-up she thought, paddling onwards (181).

Like Laura and Harry, Meredith awakens the enchantress (adult) part of herself (significantly, it is her thirteenth birthday), while at the same time quietening the island with the ancient feminine power of a lullaby. As in Dangerous Spaces, Mahy concludes the novel by stressing the importance of Meredith's reintegration and, as a sign of her maturity, the growing irrelevance of her island/isolation fantasy:

...carefully carrying her shell and with the dogs on either side of her, Meredith ran for the Zigzag, and scrambled back over the Edge of the World to her family and her birthday dinner, while behind her Kaitangata, wrapped in its own silence, lay like a tear on the smooth cheek of the bay (181-182).

I have argued that in using the island motif couched in dreamscape imagery, Mahy's texts follow the tradition established by Treasure Island and Peter and Wendy whereby the island features as a space for child protagonists to discover more about themselves before returning home; in other words, following the typical romance pattern. On the one hand, Treasure Island and Neverland represent wish-fulfilment for Jim Hawkins and the Darling children; on the other, it is hinted that the islands would become nightmarish if one were to remain there too long, as Peter Pan does. This second notion is developed in Dangerous Spaces and Kaitangata Twitch, where the healthy adolescent desire for independence symbolised by the geographical island warps into a dangerous and unhealthy fixation with 
isolation, to the detriment of family relationships. The island fantasies of Anthea and Meredith - 'the hole in the middle of the zero', the 'circle of nothing' - reveal the hollowness implicit in excessive introspection, and by extension, the limitations of fantasy and the romance genre in providing a narrative for adolescent individuation. While the island space may seem tempting as a place of refuge and retreat for Anthea and Meredith, for Mahy the real development of adolescence must happen in the context of connectedness to family (and to the land, as in Kaitangata Twitch), not in a space that by definition is isolated. Initial feelings of crampedness by the protagonists notwithstanding, Mahy shows the realism of domestic life in a positive light not found in Treasure Island or Peter and Wendy. This is largely anchored by sympathetic adult characters such as Molly in Dangerous Spaces and Lee Kaa in Kaitangata Twitch. Once Meredith and Anthea realise their familial contexts (and potentially, the prospect of adulthood) are not as bad as they supposed, the island fantasy is no longer necessary. 'To be born is to be wrecked on an island' remarks Barrie in his preface to the 1913 version of Ballantyne's The Coral Island. These words undoubtedly stir excitement in the hearts of some; Mahy, it seems, is more taken with the old adage 'no man is an island' for her normative vision of the transition through adolescence. 


\section{Chapter Three}

\section{Forest-gardens and storybook houses in Dangerous Spaces and The Tricksters}

Mahy makes complex use of the Victorian motifs of fairytale forests, secret gardens and storybook houses in her novels. In literary tradition, the forest and the garden are usually the symbolic antithesis of one another; the former representing wildness and danger, the latter, domesticity, nurturant growth or paradise. Mahy, however, departs from this tradition. She rarely uses imagery from forests or gardens alone; rather she collapses the differences between the two symbols, creating 'forest-gardens', which take on different roles in each novel. ${ }^{19}$ This blurring can be seen in Dangerous Spaces where the Wakefield family plant a 'forest' of nursery saplings, yet Mahy paradoxically emphasises its 'ancient architecture' (60). While the primordial forest should be dangerous according to fairytale pattern (particularly for a female protagonist), this forest is attributed garden-like characteristics. It is a safe place, in which the positive life-force of nature is to the fore. A similar collapse (with an opposite effect) takes place in The Other Side of Silence, where the forest-garden is formed by a suburban garden grown wild. While initially appearing to be the nurturing, freeing garden of Victorian literary tradition, it becomes instead the outer layer in a trap, its enclosing nature shown as analogous to the manipulative silence protagonist Hero has adopted in an attempt to gain a more powerful position within her family.

Within the Victorian children's literature canon, the archetypal garden can be found in Frances Hodgson Burnett's The Secret Garden (1911), while the archetypal forest is found

\footnotetext{
${ }^{19}$ I have adopted 'forest-garden' for this conflation. Diane Hebley uses the term 'garden-forest' in passing in 'A Fertility and Felicity and Ferocity of Invention': New Zealand Landscapes in Margaret Mahy's Young Adult Novels'.
} 
chiefly in fairytales. ${ }^{20}$ As feminist fairytale critic Ruth B. Bottigheimer has noted, 'the great German woods and forests' are 'essential textual images in Grimms’ Tales' (103).

The notion that a journey into the fairytale forest symbolises self-discovery (the bringing of the unconscious self into the light of consciousness) is inescapable, thanks to the work of Carl Jung and Jungians like Bruno Bettelheim. More relevant here, however, is the interpretation of Bottigheimer, who suggests that a key difference between the forest experiences of male and female protagonists in fairytales is the level of isolation implied. Arguing that the forest itself 'embodies and expresses non-community' (102), she particularly notes the pattern in which girls who have wandered into the forest are obliged to spend their time alone, either to await rescue, or to protect themselves from danger (for example, in Snow White, the dwarves admonish the heroine whenever they leave her to 'be sure to let no-one come in'). Female isolation in fairytales tends to last far longer than that experienced by their male counterparts; as Bottigheimer concludes, 'isolation in the Grimms' tales, like silence, has a female face, and it is most frequently seen in the forest' (111). The implication of this seems to be that the passive, silent nature of the female foray into the fairytale forest results in a more limited form of the heroic journey, a notion that I will return to later in my discussion of The Other Side of Silence.

The isolating function of fairytale forests can be contrasted with the integrating function of the outdoors found in The Secret Garden. The Secret Garden tells the story of Mary Lennox, a young English girl who, after becoming orphaned in India, goes to live with

\footnotetext{
${ }^{20}$ Fairytales and The Secret Garden are the works of Victorian literature for young people that Michael Ferber chooses to mention in connection with each motif in his Dictionary of Literary Symbols (Ferber, 78, 82). I must explain here my categorisation of fairytales as Victorian; while some of the Grimms' fairy tales appeared in England in 1823 - anticipating the ascension of Queen Victoria by 12 years - it was not until the mid-nineteenth century that the fairytale became widely read in England (for example, in Andrew Lang's popular Fairy Book collections, published between 1888 and 1910). Thus fairytales from the European tradition are in a very real sense 'Victorian'.
} 
her gentleman uncle Mr Craven in Misselthwaite Manor, on the Yorkshire moors. Sickly and 'contrary' when she arrives, Mary discovers two secrets during her time at Misselthwaite that encourage her to change the way she thinks and acts: her cousin Colin, a boy her own age ensconced as a hysterical invalid in a hidden part of the manor, convinced he will die young; and a locked secret garden, placed out of bounds by Colin's father because it was the site of his wife's death. Having discovered the seemingly barren and untended garden, Mary sets about coaxing it back to life, with the help of Ben Weatherstaff, and Dickon and Martha Sowerby. Developing patience and the ability to care for something outside herself, Mary also physically benefits from the exercise and fresh air. Burnett parallels the initially thin, bloodless Mary with the seemingly dead 'thin grey or brown branches' (65) and the buried bulbs that 'did not seem to have enough room to grow' (67). Mary's realisation that 'it isn't a quite dead garden' (67) and her work to clear the bulbs and give them room to 'breathe', results in 'glimpses of royal purple and yellow unfurling among the stems of crocuses' (126) and 'swelling leaf-buds on rose branches that had seemed dead' (128). Eventually, Mary's new lease on life encourages her to share the secret garden with Colin, whose exposure to the garden allows him to shake off his hypochondria and walk again. The secret garden, abandoned as Mary has been, but with potential for growth and renewal, is thus symbolic of Mary's emotional growth and renewal of spirit.

The house representing enclosure is a feature of the Victorian sources regardless of whether there is a garden or a forest present. In The Secret Garden, we have Misselthwaite Manor, a rambling mansion filled with gloomy rooms and secrets. In fairytales, the gingerbread house in 'Hansel and Gretel' springs to mind, or grandmother's house in 'Little Red Riding Hood' and the witch's house full of caged birds in 'Jorinda and Joringel'. In none of these examples does the adage 'as safe as houses' apply. Misselthwaite Manor is 
associated with isolation and illness and contrasted to the health-giving garden, while houses within fairytale forests can be the very source of danger, as in the examples above, where the danger of imprisonment is ever present.

Elizabeth Wein has isolated a relevant template that underlies many stories for children. That is, the enclosing house (often haunted, or what she terms 'sentient') and the liberating garden complement each other to enable the protagonist's emotional growth:

A child, recently orphaned, goes to live with an aunt or uncle in the family's ancestral home. Longing to return to his or her own happier past, the child is receptive to the past life of the old house where he or she now lives, and to its former inhabitants. The child becomes familiar, even friendly, with the ghost of an ancestor; the child may be able to go back in time to visit his or her new friend. An attempt is made to keep the living child in the past, or even to bring about the child's death. When the child realizes that his place in time is in fact in the present, with his new family, the ancestral ghost vanishes or ceases to be malignant (249).

As Wein observes, the presence of ghosts in the house (who particularly communicate with the child protagonist), and the potential for the child to engage in either literal or figurative time-travel (often to communicate with their own ancestors), serves to 'awaken the protagonists to an awareness of family, time and endurance' (247). In her analysis of The Secret Garden, she notes that although there is no time-slippage in the novel, implicit or otherwise, 'Misselthwaite Manor is nonetheless a house trapped in the past', since Archibald Craven, Mary's uncle, 'has attempted more or less to stop time, unwilling to accept that anything good will ever happen again after his wife's death' (255). The spirit of Lilias Craven figuratively haunts both the house and the garden. However, while the past is 
oppressive within the house, in the garden death and the past are seen for what they are: part of the natural cycle of growth. As Wein concludes:

the image of the growing, changing thing of seemingly eternal beauty is not so much in contrast to the often deteriorating solidity and age of the house itself, but a counter and a balance to it. [...] An old house is a link to the past; its garden is what brings the past into the present through the green of spring, change, and continued life. The house is the container, the memorial; the garden offers continuity, reality, promise. They complement each other, and together, they reflect the human condition, with all its connecting lines of family and ancestry (256).

Thus, according to Wein, the enclosing house and the liberating garden complement each other to enable the protagonist's emotional growth. On one hand, Mahy's Dangerous Spaces and The Tricksters conform to this template isolated by Wein. On the other, however, Mahy complicates the symbolic functions of gardens and forests found in Victorian children's literature by collapsing the traditional differences between the forest and the garden motifs. We have seen how Mahy reinvents the island as a 'dangerous space'; she also reinvents the forest as a safe place.

The house in Dangerous Spaces represents a link between the house's current occupants and its past, while for Anthea, the conflation of primordial forest and domestic garden signifies her connection to the present and future with her family, drawing her back from a dangerous descent into suicidal fantasy. Two of Wein's key motifs: 'the haunting of the child by an ancestor', and 'a sense that the house itself is the vehicle for the ghost's existence' (Wein, 249) are remarkably obvious in Dangerous Spaces. Old Lionel (the ghost of Flora's grandfather, who still haunts the house he built) cannot bear the changes his son's family are making to the house. His ghost seems to pervade the very materials of the house, as Flora's 
father tells his family, 'sometimes I think [Old Lionel] hammered bits of himself into the house when he added on to it, and now he can't tear himself away' (48). Mahy's anthropomorphic description of the partially renovated house as being like 'living inside a sort of skeleton, skin gone, and bones, nerves and blood vessels revealed' (5-6), suggests that Old Lionel continues to possess the house as if it were his body, a body that is less susceptible to change than mortal flesh. A link is therefore established between the ancestral house and 'flesh and blood'. The connection is further underlined in an exchange between Flora and Lionel's ghost:

'What's the use of worrying about the shape of the rooms when the people of the house are giving up and getting ready to go,' Flora cried. 'Houses wear out! They have to be changed.'

'Families change!' repeated the faint voice beside her. 'Wood and tin keep their shape longer than flesh and bone.' [...]

'I'm your true house,' she said fiercely, holding her arms wide so he could take a good look at her. 'Well, part of it. So's Anthea. Why go haunting wood and nails while the blood gets lost in nothing?' (112).

Mahy's text strongly suggests the importance of the natural succession of the older generation by the new. As Flora tells Anthea, 'It's funny about space. You have to have it, but you can't just stay in it forever. You have to make way or there's nowhere for anyone else to go' (127). Old Lionel's overly-long possession of his house shows an unwillingness to confront his own mortality, and in doing so, concede his space to his descendents. Having lived a long life, Old Lionel's natural place is on the island at the centre of Viridian, the realm 
of the dead. Without his realising it, Old Lionel's possession of the house is also a kind of self-imprisonment, preventing him from reaching his natural end.

Similarly, Anthea's unnatural desire for space (in the form of a suicidal retreat into the fantasy world of Viridian) represents a trap for her, one which is finally broken by the realisation that she belongs in the present, with her new family. Anthea's growing relationship with her family is symbolised by the forest of seedling trees planted by Anthea, her aunt (and adoptive mother) Molly, and her cousin Flora. Together, the three of them create a forest-garden, which connotes both the domestic and the fantastic. The forest-garden is explicitly linked to fairytales and magic; Molly tells the girls only half-jokingly, 'one night we'll probably see strange things coming out of it - magical green people, unicorns...' (58). Mahy particularly emphasises the powerful natural force of the trees themselves and their ability to bring about seemingly magical transformations:

... trees had wonderful powers. They had an ancient architecture [...] They had a dark phase and a light phase; they could outlive man and break stone, taking from the earth and giving back to it.

'Trees are magic. We're planting a whole forest of green magicians,' [Molly] declared (60).

Mahy's imagery here recalls The Secret Garden; where Burnett describes the garden as having reached 'the time when every day and every night seemed as if Magicians were passing through it drawing loveliness out of the earth and the boughs with wands' (150). Mahy seems to be echoing Burnett's use of magic, which Phyllis Bixler describes as 'a unifying metaphor for the various kinds of transformations in [Burnett's] book' (57). 
The transformation in Mahy's novel is Anthea's transition from desiring isolation to understanding the need for social integration with others. Planting the forest is the first time since her parents' death that Anthea has begun to enjoy spending time with her new family, and the appeal of her dangerous dream world begins to fade a little:

All that time [planting the forest] she had been entertained, even happy. It seemed to her then that she must have somehow carried some of the space of Viridian back into the everyday world with her (62).

It is fitting, then, that the image of the forest planted by the family invades her dream, reminding her of all she has to lose in the real world. ' $[\mathrm{H}]$ undreds of saplings' break through the 'old stone' of an abandoned coliseum, 'erupting eagerly towards the light, shattering the stone as they grew' (68). Anthea finds herself 'looking into a forest haunted by the memory of an ancient ruin, rather than a ruin overgrown with trees' (68), suggesting that while the coliseum is an image of stasis and death, the trees symbolise dynamism and vitality. Again, there is an echo of The Secret Garden, in which Colin, too, dreams of the transformational power of the garden, telling Mary 'I heard you say something about grey changing to green, and I dreamed I was standing in a place all filled with trembling little green leaves' (149, my emphasis). Mahy's forest-garden, like Burnett's garden, seems to represent the potential of life, in opposition both to the island image of death discussed in the previous chapter, and Viridian itself, which is increasingly described in terms suggestive of sterility and death - an 'empty world' (54), filled with 'old stone' and 'ancient ruins' (68), and 'a dreadful, smoky place' where Anthea is 'one of a crowd of shadows' (100). In contrast to the sterility of Viridian, Mahy endows the trees with positive traits of an anthropomorphic nature. They exhibit self-sufficiency - the ability to 'draw water up three hundred feet into the air to refresh their top leaves' and to 'change sunshine into food for themselves' (60); generosity - the trees 
also provide food 'for the animals and insects that ate their leaves' (60); and togetherness 'trees spreading out their arms towards each other, holding hands as if they might begin a dance' (74).

Despite their powerful life force however, the memory of planting trees with her new family is not enough on its own to snap Anthea out of her dangerous fantasy of remaining in Viridian forever; she needs help from Flora, who perceives the danger Anthea is in when she finds her cousin sleep-walking amongst the trees. Here, the forest-garden acts as a kind of psychic portal. Realising she needs to somehow enter Anthea's dream to awaken her, the aptly-named Flora does so by saying the word photosynthesis, 'as if the scientific word were as magical as abracadabra' (78). Each tree in the forest is 'a green magician with the power to transform worlds' (78), allowing Flora to become 'part of another world, part of Anthea's dream' (75), redolent of Jung's vision of the forest as a symbol for the universal unconscious (Alchemical Studies para 241). The universality and primordial nature of the forest image is emphasised by Mahy, despite the actual trees being only newly planted: ${ }^{21}$

From inside the house it had looked like the first forest of the world. Out here, Flora found it was hard to tell just how high the trees really were. Those directly in front of her seemed no taller than they had been when she had held them upright for Molly that afternoon, whereas those at the edge, the ones seen from the corner of her eye, looked tall and old. Yet, when she turned and confronted them, they, too, dwindled into mere saplings, while the middle of the forest grew ancient and tall, its trees spreading out their arms towards each other (74).

\footnotetext{
${ }^{21}$ In The Changeover, the primordial, universal nature of the forest in which Laura's changeover takes place is similarly emphasised: 'the forest that was all forests, the forest at the heart of a fairytale, the looking-glass forest where names disappeared, the forest of the night...' (216). For more detailed discussions of the fairytale forest as emblematic for Laura psychological journey of self-discovery, see Gose's 'Fairytale and Myth in The Changeover' and Raburn's 'The Changeover, A Fantasy of Opposites'.
} 
Here Mahy's forest-garden matches the garden of Wein's template; a transformative and life-affirming counter-point to the house's unnatural crystallisation of the past. Like Burnett, Mahy has joined the two motifs so that the house loses its sinister and enclosing nature, allowing Anthea both the space she craves and the connection to the family unit, and rendering her dream world redundant. Where Mahy stands out, however, is in her unique creation of the forest-garden, where she collapses the differences between the two images. The primordial forest should be dangerous according to fairytale pattern, yet, since it is manmade, garden-like characteristics are attributed to it; it is a safe place, in which the positive life-force of nature is to the fore. At the same time, the universal nature of the forest remains present, evoking the fairytale journey of psychological discovery.

The unnatural recurrence of the past is also a feature of The Tricksters. As we shall see, in this novel, both the garden and the house are tied to the past (and are therefore potentially dangerous and limiting), since the garden is an extension of the domestic space, rather than a counter-point to it. The balance is provided by Mahy's introduction of the wild bush into the imagery, the suggestion being that the wild, the cultivated and the constructed are all necessary to facilitate the personal integration of protagonist Harry.

Edward Carnival, colonial settler and original owner of Carnival's Hide, the house Harry and her family now holiday in at Christmas some 90 years later, is described as both a 'pioneer of forestry' (14) and a 'prodigious gardener' (15); immediately associating the forest with the garden as if they are the same thing. In this novel, it is the cultivated forest (with its colonial overtones) rather than the wild, fairytale forest that comes to the fore; as Harry notes, Edward 'wanted to make the place into something like the Garden of Eden' (47). He continues this God-like assertion of authority when bringing up his own children; as Naomi, Harry's mother explains, Edward 'wanted to train them up like good forest trees' (46), 
inventing 'his own educational system, which seems to have been based partly on one of those return-to-nature ideas - man being always happy close to the earth in his natural state' (46). Part of his system of 'education' included schooling his children on the repression of emotion. Like Mary in The Secret Garden, the children themselves found an outlet for their loneliness in gardening, creating elaborate fantasies using garden tools as props. Edward's cultivation experiment inevitably backfired, however, when he was attacked by his emotionally repressed son Teddy. As a result, Edward killed his son in self-defence using a spade. For Edward's children, then, the cultivated forest-garden was not a safe place, but one of oppression, danger and death.

Rose Lovell-Smith has noted that Carnival's Hide contains one of the tropes of the classic Gothic house, the secret space, which serves to make the house seem 'somehow bigger on the inside than the outside' ("On the Gothic Beach" 101). Her particular examples are Harry's writing space hidden in the attic, and the nearby beach, a place that seems part of the Gothic house, even though it is outside. Just as (according to Lovell-Smith), the nearby beach is a New Zealand version of a 'Gothic' space, so too is the garden, with its terrible history. This reversal of the Victorian ideal of the garden as a nurturing space once more collapses the difference between forests and gardens, allowing Mahy to return to her familiar theme of integration, suggesting that something powerful and beautiful comes from allowing the intermingling of the natural and the cultivated, the wild and the introduced:

Native bush grew darkly in the gullies; the gorse ridges were freckled with the gold of gorse and broom. The two landscapes ran into each other and made a new countryside altogether (not pretty, but desolate, beautiful and timeless) (29).

Carnival's Hide is embedded within both landscapes - the wild and the cultivated, old and new. The initial description of the house suggests the fluidity between the house and the 
surrounding flora: 'enclosed in a great, green, summer bouquet of poplars and silver birches, the steeply pitched, iron roof of the house, also green, rose up like a magician's sign' (9). In keeping with this organic description (and with Wein's sentient house template), the house itself seems almost alive, 'groan[ing] and murmur[ing]' (20). The house is haunted by the murderous events of the past, as well as what Ruth Feingold describes as 'Edward Carnival's initial colonising impulse' (211). As in Dangerous Spaces, the house and its former inhabitants are so insistently linked by Mahy that when the mysterious Carnival brothers appear, as reincarnations of the murdered Teddy, the house responds in kind, 'twist[ing] itself back to another time' (181). Furniture shifts in the night and the original decor rematerialises, as if 'the hall had resumed its earlier dress and now waited to be recognised by old friends' (185). Here, we see a particularly vivid example of Wein's time-slip, a 'Gothic' house literally trying to take itself back in time.

The porousness of the boundary between house and the outside (noted by Lovell-Smith) applies to all aspects of the environment. Rather than staying in her secret space within the house, which as Lovell-Smith rightly notes is the site of both her creative power as a writer, but also of damaging solitude (107), Harry ventures out into the landscape where she undergoes a kind of apotheosis. Although standing on the beach rather than in the forest or the bush, it is the personal integration with all aspects of nature - 'She saw everything... every blade of grass, every grain of sand, every wave' (328, underlining mine) - that Mahy seems to suggest is necessary for Harry's development. Harry is then able to return to her writer's attic without fear of loneliness and isolation. In other words, as with the forestgarden in Dangerous Spaces, the natural world, including the 'persistent green' of the wild bush, offers Harry 'continuity, reality, promise' (Wein 256), in counterpoint to the potentially dangerous introspection of the attic space. 
Mahy thus dissolves the differences between forests and gardens. The wildness of the forest imagery that Mahy employs is not always foreboding and isolating, as seen in fairytales, although it may seem like that on the surface. Likewise, her garden settings complicate Burnett's vision of the nurturing garden in that they are sinister and full of secrecy. Mahy's forest-gardens have powerful life forces of their own that enable the transformation of the heroes by reminding them of their connections with their families and the land of the living, or by symbolising growth and renewal in ways that her gardens do not. The conflation enables the various negative connotations (danger in the forest, unnatural cultivation in the garden) to be outweighed by the positives, resulting in an image of a powerful natural life force that facilitates psychological development for the novels' protagonists.

Furthermore, by merging the imagery of gardens and forests, writing for example, of gardens grown wild or forests planted by human hands in domestic spaces, Mahy seems to be responding to the question of what can be considered natural or unnatural within the New Zealand context. New Zealand is a country in which 'forest' can connote both straight rows of the imported species pinus radiata, which may only see 30 years' growth before being harvested for export, as well as native bush such as Waipoua Forest in Northland, home to the ancient Kauri tree Tāne Mahuta. In cities such as Christchurch - the 'Garden City' where Mahy lived for many years - gardening was a significant pursuit for colonial settlers, intent on transforming the alien landscape into something more familiar. ${ }^{22}$ Within these contexts, Mahy's gardens and forests (and houses) seem to be full of the ghosts of New Zealand's colonial past and Euro-centric literary traditions.

\footnotetext{
${ }^{22}$ Katherine Raine, in her essay 'Domesticating the Land: Colonial Women's Gardening', quotes Jane Deans, a late nineteenth-century settler in New Zealand, speaking of colonists' duty to 'reclaim [the plains of Canterbury] and make them useful or beautiful as a garden' (91). Raine goes on to note that in this way, colonists intended to bring European form and order to the chaos of nature.
} 


\section{Chapter Four}

\section{Cultivating Heroes: The Forest-Garden in The Other Side of Silence}

In The Other Side of Silence, the three motifs discussed in the previous chapter (that is, the forest, the garden and the storybook house) converge in the main setting of the novel - the property of Miss Credence, a local eccentric. The house, the last property in the suburb that has not been subdivided, stands in the middle of large grounds that are part enclosed garden, part semi-wild forest: 'It looked like a house in a storybook. In front of it spread the forest, full of trees that had been planted on purpose, and many other accidental ones... seedling sycamores and wild plum' (4). But in The Other Side of Silence (unlike Dangerous Spaces), the natural power of the garden fails to balance out the danger posed by the house. Instead, both the garden and the house are shown to be potentially dangerous - literally, and as a symbol for the protagonist being constrained by restricting self-expectations and the expectations of others.

Twelve year-old Hero, like so many of Mahy's heroines, feels the need for solitude from her over-educated and hyper-verbal family, and sees Miss Credence's house as the perfect place of retreat. Hero, imagining herself as 'a spirit of leaves and air' (5), climbs daily up the trees in the neighbouring park, over the high wall enclosing Miss Credence's property and into the trees that grow in the garden, moving from one tree to another without having to set foot on the ground. From this vantage point, Hero watches Miss Credence feeding the birds in her forest, and contemplates the difference between 'real' (mundane, family) life and 'true' life: 'Real is what everyone agrees about. True is what you somehow 
know inside yourself. [...] You could go in and out of true life, but it had no beginning and no end. Real life always began with breakfast' (27).

As in her other novels, Mahy makes her Victorian sources clearly visible to the reader. Hero neatly illustrates this as she comments on being a 'word child' (that is, a member of a family for whom words, books and theories are highly important):

Supposing I had been turned into a book back then, I would have wanted to turn into The Jungle Book, the story of Mowgli, a boy who lived in the jungle and talked the language of the animals, or I might have made do with The Secret Garden. But I would probably have turned into Old Fairy Tales, which was the book everyone read to me when I was small - the book I used for secret advice... for divination (8).

A motif common to The Secret Garden, Rudyard Kipling's The Jungle Book, and fairytales (particularly 'Bluebeard' and 'Jorinda and Joringel', fairytales Mahy explicitly alludes to in this novel) is that of isolation (by imprisonment or constraint, whether literal or psychological). As Bixler notes, in The Secret Garden, the walled and locked garden is symbolic of Mary's, Colin's and Mr Craven's psychological isolation (70); Colin in particular is kept confined to his room, imprisoned by ill-health that is largely psychosomatic, brought on by his father's rejection. Bluebeard attempts to control his wife's movements, forbidding her access to a secret chamber within the house; while in 'Jorinda and Joringel', the witch imprisons Jorinda in a bird-cage. In The Jungle Book, Mowgli, having been raised in the jungle by wild animals, is increasingly stranded by his lack of human language. ${ }^{23}$ As

\footnotetext{
${ }^{23}$ Mahy discusses her early fascination with The Jungle Book in her essay 'Endings and Beginnings'. As a child, she tried (unsuccessfully) to convince her school friends (and herself) that she could communicate with animals. She goes on to acknowledge The Jungle Book as one of the foundation stories of The Other Side of Silence alongside her adult interest in the language acquisition of feral children, the implication being that the mute character of Rinda is 'an adult acknowledgement of what a wolf-child like Mowgli, a human brought up without human language, might really have been like' (Mahy "Endings and Beginnings", 2000, 22).
} 
Wendy Doniger O'Flaherty notes, Mowgli is trapped, unable to properly integrate into human society, nor remain in the animal kingdom (78). As we shall see, imprisonment of various forms is a significant theme also to be found in The Other Side of Silence.

There are obvious parallels between The Other Side of Silence and The Secret Garden, beginning with each protagonist's illicit entry into the garden. Unlike Mary, Hero does not find the key to the garden; rather, she uses the park trees to help her climb over the wall. Both girls, however, have animal guides to help them gain entry - Mary has the friendly robin to show her where the garden door is, and Hero is encouraged by 'a ginger cat [that] sat like a sentry on the top of the wall [....] He purred as [Hero] edged towards him' (13). After Hero gains access to the garden via the tree's branches, Mahy's text directly echoes Burnett's. Thus, just as we are told Mary stood 'inside the secret garden' (Burnett, 64, italics original), so too Hero finds herself 'inside the secret garden' (14). Both girls then become gardeners themselves - Miss Credence offers Hero a gardening job when she discovers the girl illicitly in the garden, having fallen from a tree. Since Miss Credence has discovered her, the garden is no longer strictly a secret place for Hero, however maintaining secrecy is emphasised for Hero as much as it is for Mary (who is afraid of her uncle discovering she has entered a place forbidden to her). Indeed, as Miss Credence explains to Hero, she is offering Hero the job because of her unique ability to keep a secret, as she is a selective mute: '... I like to be private, and I don't want anyone coming in here for any reason, and then chattering about me out there. So from that point of view, I quite like the idea of a gardener who won't say anything' (20). ${ }^{24}$ While Hero's parents are aware that she has the gardening job, Hero's

\footnotetext{
${ }^{24}$ Selective mutism is defined in The Journal of Psychology as 'a disorder characterised by a persistent failure to speak in certain social situations. It is typically diagnosed in childhood, and the disorder can last from just a few months to several years in some individuals. Debate surrounds the origins and causes of this disorder. Recent literature suggests that selective mutism may be a form of social phobia' (Krysanski, 29).
} 
mutism means she remains silent about her employer's eccentricities, and her growing suspicions that something is seriously wrong at the house.

Hero's silence links her to Mary, who is described as 'queer [and] unresponsive' (16) early in the novel. They are initially both isolated outsiders; Mary's parents' lack of interest in her has in turn led to her 'contrary' manner towards others. This isolation continues after she has arrived at Misselthwaite; her uncle is rarely present and the housekeeper informs her 'you mustn't expect that there will be people to talk to you. You'll have to play about and look after yourself' (18). Hero too is isolated, but her isolation is self-imposed, projecting what she feels as suffocation within her verbally assertive family. Hiding and silence, therefore, becomes 'the way in which I had made myself special, made myself powerful in a family in which everyone struggled to find their own power' (164).

The motif of the invalid confined in a secret room within the house is a further parallel between the two novels. Rinda Credence is imprisoned in the attic by her mother, who is disturbed and mortified by Rinda's lack of mental development, while in The Secret Garden, Colin is confined to his room, both because of fears about his health, and because his father does not like to be reminded of his wife's death by seeing his son. In both novels, the female heroine is alerted to the presence of the secret room by the screams of the confined occupant, leading each heroine to become curious and travel through forbidden parts of the house to discover the origin of the sound. Further, both Hero and Mary take on the transformative role of saviour - in Mary's case by nursing Colin back to health, and in Hero's, by literally saving Rinda from imprisonment in a tower.

However, the garden plays a significantly different role in each novel. For Mary, the garden space is inextricably bound up with feminine growth and nurturing; for Hero, the 
garden, while initially representing escape, is eventually revealed as the outer layer of a series of concentric prisons that culminate in the tower in which Rinda is confined. ${ }^{25}$

As with the island and Wonderland images previously discussed, the symbolic meaning of the enclosed garden image is ambiguous. In The Secret Garden, critics have noted the paradoxes inherent in cultivation (which is both regenerative and unnatural) and enclosure (which can make a garden both safe and restrictive). This ambiguity has given rise to opposing interpretations its central image. Bixler argues that the garden "provides a near utopian vision of female nurturance' (Bixler, 18). For Bixler, the garden's apparent deadness when Mary discovers it parallels Mary's own stunted emotional growth. With the assistance of Ben, Martha and Dickon, however, 'Mary [becomes] both gardener and garden, nurturing herself even as she is being nurtured' (38). She goes on to argue that the garden (especially keeping it a secret) becomes a source of independence for Mary, where 'taking charge of the garden means beginning to take control of one's own life' (48). Less straight forwardly, Lissa Paul argues that 'the irony implicit in Mary's story is that the secret garden, the place of growth, is the place of her defeat' (196), pointing out that as the novel progresses, the garden becomes increasingly about Colin's recovery rather than Mary's independence.

From a modern point of view then, Burnett's Victorian garden can be read as both the catalyst and the container for Mary's growth. Paul also points out, however, that although The Secret Garden reads today as a 'thwarted story of independence', Mary does in fact achieve the only kind of independence that would have been possible for a girl during the period. As Paul puts it, 'Burnett ends the story in accordance with the social and economic truths and values of her particular time and place' (197). The difference between Burnett's

\footnotetext{
${ }^{25}$ Of course, as I explain later, the connection between gardens, nurturing and femininity is not always considered to be positive, particularly within feminist discourse.
} 
and Mahy's novels, then, are the values that can be ascribed to the respective gardens - for Burnett it seems that the elements of nurturing and self-sacrifice inherent within her garden constitute a form of growth and achievement for Mary (if not the independence and selfintegration we expect to see young heroines achieve today), whereas in Mahy's novels, selfintegration (both independence and strong relationships with the family) is the ultimate goal for her female heroines .

The garden is of central importance to both Hero and Miss Credence. For both, the forest-garden is the place in which they feel their 'true' lives take place. But the forestgarden's 'true' life is an illusion - in fact the forest-garden represents the limitations imposed on their lives by themselves or others. In Miss Credence's case, it symbolises patriarchal oppression, having her intellectual career limited by her father's domestic expectations of her. The house and its large grounds are symbols of the Credence family's financial success, earned and maintained through the males of the family including Miss Credence's father, 'a professor, a world figure in the field of symbolic logic' (85) and a member of MENSA. Strict maintenance of an orderly garden seems to have been very important for Professor Credence while he was alive, and Miss Credence feels compelled to carry this on after his death - even to the point of shooting a cat in front of Hero, explaining 'They prey on birds, and I just can't have that. [...] My father kept this garden strictly free of cats, and I maintain his standards' (54).

Having been initially encouraged by her father to 'take [her] place in the arts and sciences' (86), after the death of her mother, Miss Credence is obliged to step into the domestic role: 'that's what he wanted me to do... to become his mother in a way (of course she had always spoiled him, what with him being the only son) or, perhaps, to turn into my own mother' (87). While Miss Credence has taken on basic responsibility for the house, in 
general she has rejected the domestic sphere occupied by her mother. She admits that "I've never cared for housework" (86) and "I'm not a gardener. I don't even want to be" (20). Instead, Miss Credence takes on a masculine role within the garden, as if her experiences with her father have taught her that to be masculine is the only sure way to be accepted into the intelligentsia. Hence, when walking around her garden, Miss Credence 'turned herself into her father's ghost by wearing his cloak and smoking the same kind of cigarettes that he had smoked' (147). ${ }^{26}$ Yet despite this adoption of another role, Miss Credence still feels constrained by the ghost of her father, and remains within the enclosed environment of the garden - for her, the taking on of a masculine persona is in fact more restrictive than freeing, as we see revealed in her adaption of the 'Jorinda' tale. In Miss Credence's adapted tale, the evil Nocturno, wearing black cloak and hat, pursues Jorinda the bird-girl. Nocturno's 'dark wisdom' melts when he is struck by a ray of sunlight, 'and of course, he had to melt with it', as there 'wasn't much else to him beside wisdom' (52). Jorinda then puts on his cloak and hat, taking on Nocturno's persona, just as Miss Credence does by wearing her father's cloak. Thus the garden becomes a trap for Miss Credence, and representative of her inability to be her own true self, while masquerading as a space of freedom.

The garden initially seems appealing for Hero, too; a place of wild freedom where she can live her invented 'true life', and where she can maintain her silence as a tool of power. Hero has always found refuge in the world of books, particularly fairytales, which she considers to contain a 'true' version of life. Stories offer Hero a kind of protective buffer between herself and her sometimes overwhelming family. Describing her morning routine, Hero explains:

\footnotetext{
${ }^{26}$ This description of Miss Credence almost seems like a perverse echo of a passage in The Secret Garden in which Mrs Sowerby suddenly appears in the garden, 'the sunlight drifting through the trees and dappling her long blue cloak' (281). In this passage, as Jane Darcy notes, Mrs Sowerby's sudden cloaked appearance casts her 'rather like the ghost of Mrs Craven and something of a Mother Earth figure' (Darcy, 220).
} 
I would get my bowl of muesli and a slice of toast, and sink into that secret puddle of gold, with the bottom shelves of the floor-to-ceiling bookcase rising behind me. I wasn't exactly hiding. I just liked that patch of sunshine, and not solitude exactly, but being on the edge of things with all those stories guarding my back. [...] The Jungle Book, The Secret Garden, Old Fairy Tales and a whole lot of others with faded letters and peeling spines. Make me true, they would say to me, over and over again. Make me true. (29-30)

Hero's inclination to see actual gardens or forests as places of refuge (particularly when, like Miss Credence's property, they appear as in 'a story-book' [4]) is therefore unsurprising. The property, and particularly its garden, seems to exert an irresistible pull on Hero in much the same way the island does for Anthea in Dangerous Spaces: 'Garden or forest, it seemed as if I had been working my way towards it from the first time anyone ever told me a story' (14). Hero imagines that within the walls of the garden, there is a type of freedom not accessible to her at home, and that she could somehow be more true to herself within the garden, 'changing into something wonderful as [she] flew [over the wall]' (13). Once up in the trees, Hero turns into 'the true child of the wild woods, someone who had been fostered and fed by birds' (6), and she equates this desire 'to fly' with freedom and independence.

Yet the garden provides a false sense of freedom, leading Hero to be come overconfident and careless, tumbling from her tree. In accepting the gardening job, Hero also tacitly accepts the name 'Jorinda' that Miss Credence gives her, the first indication that the forest-garden is not a safe place for Hero to be. Hero recalls the name uneasily, although she can't quite remember from where. The earlier allusions to Old Fairy Tales, however, give the reader the clue that the name is taken from 'Jorinda and Joringel'. Hero worries that the name is somehow a means to control her garden activities: 
... before I had fallen out of the trees I had been able to climb and scramble through Squintum's Forest [Hero's fairytale nickname for Miss Credence's property], leaving all names behind me. Being nameless had been a kind of freedom. Now, whenever I was up in the branches I knew I was allowed to be there, and that I was casting a shadow in the kingdom below. The name was a leash that could be used to twitch me into place. And now, when I came down from the trees, in a way it was like feeding at Miss Credence's feet, along with all those other birds (23-24).

Readers familiar with 'Jorinda and Joringel' will realise she has reason to be afraid; in the fairytale an old witch turns the young Jorinda into a nightingale and imprisons her in a cage within her castle, thus depriving her of the power to speak. It seems significant to The Other Side of Silence that by turning her into a nightingale, the witch is removing from Jorinda the power of human speech.

Bottigheimer's discussion of female mutism as a motif in fairytales proves pertinent here. According to Bottigheimer's synthesis, 'enforced silence' is 'a precondition for redeeming oneself or others'. For heroines, moreover, silence 'also exists as a punishment' (Bottigheimer, 74-75). In allowing Miss Credence to give her a fairytale name, Hero becomes the passive, mute female protagonist lost in the fairytale forest. By clinging to the role of silence she has created for herself, Hero is in fact allowing Miss Credence to 'invent a story for [her]' (21). The forest-garden space seems appealing in its wild freedom, yet, like her silence, in actuality it is more restrictive than liberating. The idea of the garden as a space for freedom has failed Hero, and instead has led her into the path of the fairytale wicked witch - Miss Credence, with her black cloak and hat, and squinty eyes.

Interestingly, Hero's growing sense of oppression within the garden can be read in parallel to the potential for oppression within her mother's academic theories about education 
and growth in children. Hero's mother, Annie Rapper, is a lecturer within the education department at the local university, well known for her book on how to rear gifted children, whose theories are seemingly borne out by Hero's two very intelligent siblings, Ginevra and Athol. Annie's theories are steeped in the language of cultivation and gardening, conflating natural development with the artificial:

Her book suggested that every child in the world was a sort of genius at the same time as being perfectly ordinary, and that, if children were properly treated, the genius would naturally flower. [...] If children were lured up (Annie's words) they would all blossom into wonderful people (48).

Ginevra and Athol do 'blossom' very early on, and much is made of their innate abilities. Hero doesn't fit the pattern established by her overly wordy older siblings, instead choosing to claim attention via her silence. She seems to be torn between a sense of guilt that her silence is undermining her mother's theories and potential further success as an academic, and the feeling that to demonstrate the theories' failure will draw more attention to herself. As Kathryn Walls notes, in 'being defined by her mother as "the quiet one" (69), Hero has suffered a blow to her confidence even before she could be said to have had much confidence to lose' (191), a blow it takes most of the novel to recover from. Mahy's forest-garden does not live up to its potential for allowing freedom for either Hero or Miss Credence, nor does it have the positive, nurturing connotations that enable Mary's emotional development in The Secret Garden. Rather, it forces the two main characters to take on roles that obscure their true selves.

Showing the opposite pattern to The Secret Garden (which moves from the interior to the exterior) the action of Mahy's novel moves away from the forest-garden and into the fairytale witch's house, the second layer of imprisonment within the novel's schema. This 
reversal of movement seems to further contrast the function of the garden in the two novels, that is, for Mary, the garden is a place of escape from the constricting house, whereas for Hero, the forest-garden acts as a kind of lure into the house:

Whatever it was that had flowed from the house out into the garden, forcing Miss Credence to pose in front of me with a dead cat in one hand and a gun in the other, was somehow tugging me from the garden into the house... (85).

Miss Credence's house is overlaid with imagery from 'Jorinda and Joringel', 'Bluebeard', and The Secret Garden, all rolled into one. After Hero begins the housekeeping task she is given, she realises that although she has seen an upper story window from outside, she has never been upstairs in the house, or even noticed a staircase. The house is haunted metaphorically by its past secrets, an illusion of sentience lent by strange sounds heard at intervals inside the house, a 'gobbling' that Miss Credence tries unconvincingly to blame on old pipes. Forming a horror-movie suspicion that Miss Credence has revenged herself on her father by trapping the elderly man in the attic and passing him off as dead, Hero decides to solve the mystery and open the secret door to the upstairs part of the house. Cracking the door's pin code, Hero climbs the stairs, to find not Miss Credence's father, but instead her illegitimate and intellectually disabled daughter, Rinda. Rinda's prison, the secret room within the house, is at once Colin's secret room in The Secret Garden, the secret and forbidden chamber in 'Bluebeard', Rapunzel's tower, and Jorinda's cage. In a post-modern touch, Hero is acutely aware that her story conforms to fictional stereotypes and of the intertextual nature of that story, as narrator Hero tells the reader 'so I went on, with the story dissolving and changing around me' (140).

In Charles Perrault's tale, Bluebeard informs his new wife that he has to go on a journey for several weeks, but that she should avail herself of the fineries of his house in his 
absence. Giving her the keys to every room in the house, he departs, leaving her with the warning that she may go into any room, except one in particular, which is forbidden. Bluebeard's wife explores the house, and finally, overcome with temptation and curiosity, opens the forbidden chamber, whereupon she finds the corpses of Bluebeard's previous wives, murdered and hanging from the walls. She drops the key in fright, and it gets covered in blood that cannot be removed, despite her best cleaning efforts. Given away by the bloody state of the key, Bluebeard declares he will kill her too, irate at his wife's disobedience. She begs for forgiveness but he remains unmoved; at the last moment before he cuts her throat her brothers burst in and rescue her, killing Bluebeard.

There are clear parallels between The Other Side of Silence and this tale. Bluebeard's wife (who, interestingly, is never given a name) is at least partially attracted to Bluebeard because of his great wealth and fine things; Hero is drawn deeper into Squintum's House by the lure of extra pocket money. Bluebeard, while forbidding his wife to open the chamber, yet giving her the key, seems almost to want his guilty secret to be revealed (and perhaps to be forgiven or redeemed by his new wife). ${ }^{27}$ Since Hero began working for Miss Credence, there has been the spectre of a secret haunting Miss Credence. But it is a secret that Miss Credence seems desperate to share, oscillating between dropping hints to Hero about her hidden daughter and reverting to unconvincing cover-up stories. She effectively gives Hero the key to the secret chamber, dropping hints as to where the key code can be found:

"Be careful with everything on the desk," she said at last, speaking with the same curious deliberation I had heard in her voice before. "Everything's set out in special

\footnotetext{
${ }^{27}$ As Maria Tatar explains in her comprehensive study of the tale, in Bluebeard's offer of a key to his wife, he 'establishes intimacy and trust at the same time that he invites disobedience and betrayal' (52).
} 
piles." And then she stared hard at the top of the desk, frowning at something in such a way she seemed to be pointing it out with her eyebrows (119-120).

The object Miss Credence is 'pointing out with her eyebrows' is her birthday book, open to the page with the key code to the garden gate written in pencil. With this clue established, it does not take Hero long to find the code to the upstairs part of the house, written on the page of Rinda's birthday, 'almost as if someone wanted it to be easy to find' (124). By now, Hero has realised the sinister twist her story is taking:

The story I was part of now was even more famous than The Jungle Book. Everyone knew it, even people who didn't read. It was the tale of a bride who was allowed to go anywhere in a house except for one forbidden room. Of course, in the end, she couldn't resist going into that room, and found other brides, all strangled, hanging there. The name of the story is Bluebeard.

Despite understanding that what she is doing is forbidden, and that 'in fairy stories the girl who goes into the forbidden chamber will meet a terrible doom' (139), Hero feels compelled to enter the upper part of the house. In this respect, Mahy departs very significantly from the Bluebeard tale, for Hero's compulsion is not idle curiosity nor a wife's quest for intimate knowledge of her husband; instead Hero is driven by the feeling that she is 'doing something that ought to be done' (140).

Once inside the upstairs room, Hero discovers the true identity of the captive, Rinda. The fairytale significance of Rinda's name is not lost on Hero:

There was nothing pretty about Rinda. She hadn't become a nightingale like Jorinda in the story, and she wasn't any kind of Rapunzel. No rescuing prince could ever have climbed her thin, brown straggling hair (142). 
While no beautiful bird, Rinda has been caged, nonetheless, by her own mother; horrifically, the way that the 18-year-old Rinda 'stooped forward like an old woman' makes Hero realise that 'Rinda had been held like this for so long she had taken on the pattern of her chaining' (143). Miss Credence's hopes of intellectual grandeur, her dream of being 'a bird-girl - to break out of the cage and fly' (121), have been dashed by first her father's expectations and then her pregnancy out of wedlock. Miss Credence then repeats the cycle of restriction, becoming the witch in the 'Jorinda and Joringel' fairytale instead of the heroine she dreamed of being, caging first her daughter and then Hero in the attic.

Rinda is triply imprisoned - literally chained to her bed in the attic, trapped by her cognitive disability, and unable to communicate intelligibly due to psychological abuse from Miss Credence, who 'never spoke to Rinda' (174). Hero, too, is psychologically confined by mutism; however, hers is by choice, a kind of rebellion against a family that is constantly talking. The parallel between the two girls is not lost on Hero, who recognises in Rinda a kind of twin - a horrible example of the imprisoning effect and loss of personal power that silence creates. Hero also realises that, like the bars keeping Rinda prisoner in the attic, which are made of wood, not metal, her silence is more an illusory restriction than a real one, exclaiming 'I had been looking at the idea of a cage, rather than a real one' (156). By the end of the novel, these versions of imprisonment have been reversed or undone - Miss Credence is in a vegetative state, herself unable to speak after a botched suicide attempt, while Rinda has been freed from her attic and is slowly learning to communicate. Hero, too, breaks free of her self-imposed prison of silence, realising that speaking with her own voice will always command more power than relying on manipulative silence to gain attention. In this way, Hero subverts the fairytale pattern of the silenced and passive female protagonist (outlined by Bottigheimer) by saving both herself and Rinda, becoming the true hero implied by her name. 
To conclude, the garden in The Other Side of Silence does not offer a nurturing, creative space in which the female protagonist can develop into maturity. Rather, the garden is a place in which dangerous 'invented lives' (3) must be adopted and one's true self becomes obscured through a false fantasy of freedom and independence. The garden takes on the traditional forest guise in which Hero becomes isolated and lost, following the pattern for many female fairytale protagonists. The plot then continues the fairytale pattern into the house, ruled by Miss Credence, a monster figure combined from Bluebeard and the witch from 'Jorinda and Joringel'. Mahy reverses both types of roles occupied by females found in the Victorian sources; by challenging the previously idealised relationship between Victorian garden and female protagonist, Mahy seems to be rejecting the morality of The Secret Garden in which nurturing roles are favoured for girls. She also rejects the passivity and enforced silence typically found in fairytale heroines, favouring instead a more balanced model for adolescent girlhood - in which Hero is able to both save others and call for help herself. Thus Mahy's adaptation of the meaning of the forests and gardens found in the Victorian sources reflects a change in what it means to be a heroine - or Hero. 


\section{Conclusion}

In the previous chapter we have seen how the forest-garden and the storybook house within are dangerous for Hero because they isolate, enclose and encourage silence. The enclosing forest-garden in the Other Side of Silence and the dangerous island in Dangerous Spaces and Kaitangata Twitch project the passive and limiting roles for females found in Mahy's Victorian source material. Mahy's response to the Victorian heroine is to portray more active heroines who ultimately reject these passive roles. Instead, they develop a sense of self-awareness and emotional maturity not shared by characters such as Alice, or fairytale protagonists. Thus we see Laura, who 'wakes' herself into maturity, forgiving her father for leaving the family and becoming accepting of her mother's new relationship; Anthea, who 'rescues' herself from the brink of suicide; and Hero, who breaks her way of the literal trap of Miss Credence's house and symbolic trap of her mutism. Hero's realisation that she is trapped within a story authored by Miss Credence and her refusal to accept the story's trajectory (i.e. enclosure and lack of voice, as in 'Jorinda and Joringel') enables her to escape the trap. The true (or should that be the real?) nature of Hero's heroism is shown by her eventual awareness as narrator of the limitations of forests and gardens as fantasy spaces, and the limited use of fantasy itself in determining her own path.

There is a suggestion in The Other Side of Silence, I think, that fiction itself can be dangerous, in that story-telling represents a form of control over others. We are invited to share Hero's fear that Miss Credence's story of Jorinda and Nocturno has 'sucked her in' (51); just as in Miss Credence's reinvention, Jorinda 'could never be set free' (101), Hero too fears that she will somehow become part of the story and lose her autonomy (in the way that Rinda actually has). This is coupled with a distinct anxiety about the potential for fantasy to 
become dangerously overwhelming and to remove one from the reality of human relationships. Miss Credence's insistent repetition of half-truths mixed with fairytales demonstrates her inability to recognise the horrific truth about her imprisonment of her own daughter - she requires this insulation of self-delusional story-telling to function. As we have seen, this concern about fantasy is common also to Kaitangata Twitch, The Tricksters and, most obviously, Dangerous Spaces. An over-reliance on fantasy as a means to avoid the difficult task of getting on with family is like a dangerous and addictive drug for Anthea, while for Hero, the fantasy of being a wild and free 'bird-girl' results in her confinement at the hands of Miss Credence. Investigation of Mahy's relationship to Victorian children's' literature has exposed a recurring theme, that is, the tension between what Lisa Scally calls Mahy's 'self-conscious' literariness (131) on one hand, and an anxiety about the nature of fantasy on the other.

Mahy's works are saturated with intertextual references. ${ }^{28}$ Moreover, an overarching theme of writing, authorship and the creation of fiction can be discerned in Mahy's work. Characters who are authors themselves are everywhere: Harry in The Tricksters; Tabitha in The Haunting; in The Other Side of Silence, Hero, her brother Athol, their mother Annie Rapper and Miss Credence can all be said to be authors of one kind or another. For Hero, becoming an author is empowering; as Michael Pohl puts it, she:

transcend[s] the passive helplessness of her mythical namesake [from Ovid's classical story of Hero and Leander] and grow[s] into the literal meaning of her name,

\footnotetext{
${ }^{28}$ I have already noted several critics who have focused on fairytale intertexts in Mahy's novels; in addition to my own work on Victorian sources, Michael Pohl has written a thesis illuminating Mahy's classical allusions (Pohl), and I hazard there is sufficient material for theses to be written similarly cataloguing Mahy's allusions to Shakespeare and the Bible.
} 
becoming not Hero, a literary character whose narrative is written by others, by authors, but the hero, and author, of her own story (81).

Then there are those that are fascinated by the power that words hold: Sap in The Other Side of Silence carries around a book of unusual words as a kind of talisman or shield, while in Alchemy, Jess Ferrett's clever spoonerisms reveal double meanings that are often more telling than the original words. Ellis in 24 Hours and Laura in The Changeover both use words to hold power over others. For Ellis, uttering lines from Shakespeare not only figuratively lays to rest the haunting memory of his suicidal friend Simon; his speech also prevents the murder-suicide of Christo and baby Shelley by talking Christo down from scaffolding high above the ground. ${ }^{29}$ Laura employs her new-found magical powers by 'mak[ing] up the words' (153); later she ends the life of Carmody Braque simply by 'tell[ing] him he's already dead' (188).

Yet the roles of writer and reader are repeatedly shown as being risky, as they may result in protagonists becoming trapped in their own fantasy (and perhaps even delusional). Harry's fantasies literally attack her (in the form of Ovid and Hadfield) which points to Harry's deeply conflicted personality and her inability to cope with the developmental crisis she finds herself in. For author-characters such as Harry and Hero, the solution provided is to burn their books, an act of annihilation that seems to reveal Mahy's own anxiety about her

\footnotetext{
${ }^{29}$ The scaffolding image is an interesting one; it appears twice - once in The Other Side of Silence and again in 24 Hours. In The Other Side of Silence, Hero's family home is scaffolded, allowing her to creep around the outside of the building and peer in on her family members unseen, where she witnesses moments of their 'true' lives. In 24 Hours, the climax (and Ellis' epiphany) takes place atop the old city library, which is covered in scaffolding as it is renovated into apartments. Diane Hebley notes how apt it is that Ellis's epiphany takes place 'dangerously perched up on the roof of the solid old library with all the connotations of wisdom therein, yet with scaffolding for renovation to suggest the need for change' (Hebley 202). To me, the scaffolding represents a framework of language, which, at the same time as it holds Ellis and Christo from crashing to the ground, installs a barrier between the silent Hero and her verbal family - without words she can only creep around on the outside looking in.
} 
position as the arbiter of the 'true' and the 'real'. How can books (both reading and writing) provide a source of refuge for her protagonists, yet also be so dangerous that they must be destroyed?

Pohl goes on to argue, interestingly, that the literariness (that is to say, their propensity for creating narratives) of the adult characters (Annie Rapper and Miss Credence) in The Other Side of Silence has to do with what he calls 'parental authorship', where parents are 'the authors of their children's lives, and of the exclusion of the children themselves from the writing of the stories of their own lives' (85). According to Pohl, author and character (or hero) are analogous to parent and child; thus by telling her own story, Hero at once renounces the passivity of her classical namesake, and asserts herself against restrictive parental authority (in both senses of the word). Pohl's analysis, however, does not fully explain why, at the very end of the novel, Hero deletes her manuscript from the computer, rejecting the life of an author and instead seeking a more domestic happiness with her new boyfriend Sammy. To take Pohl's idea of parental authorship further, it seems clear that Hero takes Annie's interest in her manuscript as a kind of implied ownership or control that must be rejected, lest it get manipulated for another's ends:

'I read it too,' [Annie] cried. 'And Hero - you're a writer. You really are.' She said the word 'writer' as if she were announcing a great victory for Hero. As she spoke, she looked at Hero with a mixed expression, amazed, delighted, and somehow scheming. Hero struggled with feelings of betrayal shot through with astonishing pleasure (173).

Story-telling is once again shown as dangerous; in this case, the danger lies on the one hand because the written product may be somehow used to control the author, and on the other because the pursuit of writing may become all-consuming. Once Hero has deleted her 
own story, she reflects on the folly of Miss Credence, who 'continued Jorinda's story with a story of her own... a story through which real happenings twisted like dark serpents winding through a garden' (184). Meanwhile, Sammy represents the social connection that Hero has lacked, encouraging her into the real world:

Sammy began to dance beside [Hero].

'Stop that writing, listening, blinking..

There's more to life than merely thinking,

Come down now 'cause its time for lunch

Then we'll run, run, run! Keep ahead of the bunch!

Let's you and me rap out of this story

And dazzle the world with a different glory' (184).

In the end, as in Dangerous Spaces, the domestic 'real' supersedes the dangerous 'true', and both fantasy and the act of being an author are rejected by those very characters who had previously been most in need of a voice.

One could speculate that these instances might reflect guilt on Mahy's part about herself becoming an author of books for young people - a career which she might have feared was self-indulgent for a solo mother of two. Or perhaps it is the connection between authorhood and the temptation to get caught up in the vain-gloriousness of fame that creates a sense of anxiety in The Other Side of Silence. Hero reflects that 'famous people become famous by somehow stealing energy from those around them. [...] At times, just by being famous, they somehow seem to make other people less real - less true' (178-79), as if the desire to share their stories with others can make authors into a dangerous kind of vampire. Yet, Mahy's many references to other books in her work testify to her respect for fiction. 
Paradoxically, in constructing a fantasy of escape, inevitably those very thoughts from the real world that the mind is trying to escape end up infiltrating the fantasy world. John Griffith writes that Barrie's Neverland 'is an ambiguous place: one part of the psyche desires and therefore creates it; another part denies and retreats from it, insisting it is only makebelieve, when it threatens to become too real' (28). According to Griffith, the conflict between desire and fear that Barrie expresses in Peter and Wendy is 'the classic dilemma of children's literature: the conflict between staying home and running away. This conflict is also found throughout Mahy's work, usually expressed as the conflict between wanting independence and space, and being an integrated member of the family. Yet what does it mean for Mahy's fantasy worlds if, as I have argued, on a deeper level Mahy's novels display an authorial anxiety about fantasy, or the validity of fiction itself? I am left with the intriguing paradox that Mahy's work both affirms and denies fantasy as a valid means of expression, and by extension, a valid catalyst for maturation. While fantasy and literature may be dangerous, Mahy's desire for fiction constantly ruptures the surface of domestic reality, manifesting itself through insistent allusion to some of the most well-known works of fantasy for young people. 


\section{Works Cited}

Armitt, Lucie. Fantasy Fiction: An Introduction. New York: The Continuum International Publishing Group, 2005.

Barrie, J.M. Peter and Wendy. New York: Scholastic, 2002 [1911].

Bixler, Phyllis. The Secret Garden: Nature’s Magic Twayne's Masterwork Studies. Vol. 161. New York: Twayne Publishers, 1996.

Blackburn, William. "Mirror in the Sea: Treasure Island and the Internalization of Juvenile Romance." Children's Literature Association Quarterly 8.3 (1983): 7-12.

Blake, Kathleen. "The Sea-Dream: Peter Pan and Treasure Island." Children's Literature 6 (1977): 165-81.

Bogen, Anna. "'The Island Come True': Peter Pan, Wild Cat Island, and the Lure of the Real." Treasure Islands: Studies in Children's Literature. Ed. Mary Shine Thompson and Celia Keenan. Dublin: Four Courts Press, 2006.

Bottigheimer, Ruth B. Grimms' Bad Girls and Bold Boys. New Haven: Yale University Press, 1987.

Burnett, Frances Hodgson. The Secret Garden. London: Hodder Children's Books, 1994 [1911].

Carpenter, Humphrey. Secret Gardens: A Study of the Golden Age of Children's Literature. London: George Allen \& Unwin, 1985.

Carroll, Lewis. Sylvie and Bruno. Middlesex: The Echo Library, 1889.

Compan, Magali. "'Cette Terre Qui Me Ressemble": Re-Writing the Island, Re-Writing the Self in Ananda Devi's Pagli." Land and Landscape in Francographic Literature: Remapping Uncertain Territories. Ed. Magali Compan and Katarzyna Pieprzak. Newcastle: Cambridge Scholars Publishing, 2007. 
Darcy, Jane. "The Representation of Nature in the Wind in the Willows and the Secret Garden " The Lion and the Unicorn 19.2 (1995): 211-22.

Duder, Tessa. Margaret Mahy : A Writer's Life. Auckland: HarperCollins, 2005.

Empson, William. "Alice in Wonderland: The Child as Swain." Lewis Carroll's Alice's Adventures in Wonderland. Ed. Harold Bloom. New York: Chelsea House, 2006.

Feingold, Ruth P. "Gardening in Eden: Margaret Mahy's Postcolonial Ghosts and the New Zealand Landscape." Marvellous Codes: The Fiction of Margaret Mahy. Ed.

Elizabeth Hale \& Sarah Fiona Winters. Wellington: Victoria University Press, 2005. 210-33.

Ferber, Michael. A Dictionary of Literary Symbols. Cambridge: Cambridge University Press, 1999.

Gardner, Martin, ed. The Annotated Alice: Alice's Adventures in Wonderland \& Through the Looking- Glass, by Lewis Carroll. New York: New York, C. N. Potter 1960.

Gose, Elliott. "Fairy Tale and Myth in Mahy's The Changeover and The Tricksters." Children's Literature Association Quarterly 16.1 (1991): 6-11.

Griffith, John. "Making Wishes Innocent: Peter Pan." The Lion and the Unicorn 3.28-37 (1979).

Grimm, Jacob. Jorinda and Joringel. Trans. Elizabeth Shub. New York: Scribener, 1968. Hebblethwaite, Kate. "Maroons, Darwin and the Question of Humanity." Treasure Islands: Studies in Children's Literature. Ed. Mary Shine Thompson and Celia Keenan. Dublin: Four Courts Press, 2006. 24-32.

Hebley, Diane. "'A Fertility and Felicity and Ferocity of Invention': New Zealand Landscapes in Margaret Mahy's Young Adult Novels." Marvellous Codes: The Fiction of Margaret Mahy. Ed. Elizabeth Hale \& Sarah Fiona Winters. Wellington: Victoria University Press, 2005. 187-209. 
Hennelly, Mark M. "Alice's Adventures at the Carnival." Victorian Literature and Culture 37.1 (2009): 103.

Jung, C. G. Alchemical Studies. Trans. R.F.C. Hull. The Collected Works of C.G. Jung. Ed. Herbert Read Gerhard Adler \& Michael Fordham. Vol. 13. London: Routledge \& Kegan Paul, 1959.

---. Memories, Dreams, and Reflections. Trans. R. and C. Winston. Ed. A. Jaffe. New York: Vintage, 1963.

Kipling, Rudyard. The Jungle Book. New York: The Century Co., 1894.

Krysanski, Valerie L. "A Brief Review of Selective Mutism Literature." The Journal of Psychology 137.1 (2003): 29-40.

Lawrence-Pietroni, Anna. "The Tricksters, The Changeover, and the Fluidity of Adolescent Literature." Children's Literature Association Quarterly 21.1 (1996): 34-39.

Lovell-Smith, Rose. "Eggs and Serpents: Natural History Reference in Lewis Carroll's Scene of Alice and the Pigeon." Children's Literature 35 (2007).

---. "On the Gothic Beach: A New Zealand Reading of House and Landscape in Margaret Mahy's The Tricksters." The Gothic in Children's Literature: Haunting the Borders. Ed. Karen Coats Anna Jackson, Roderick McGillis. New York: Routledge, 2008. Loxley, Diana. Problematic Shores: The Literature of Islands. London: Macmillan, 1990. Mahy, Margaret. 24 Hours. London: CollinsFlamingo, 2001.

---.The Other Side of Silence. London: Hamish Hamilton, 1995

--- Kaitangata Twitch. Crows Nest, NSW: Allen \& Unwin, 2005

--- Alchemy. London: CollinsFlamingo, 2002.

--- The Changeover. New York: Atheneum, 1984.

---. Dangerous Spaces. Ed. Vanessa Hamilton. London: Penguin, 1991. 
---. "Endings and Beginnings." A Dissolving Ghost. Wellington: Victoria University Press, 2000.

---. The Tricksters. 2001 ed. London: CollinsFlamingo, 2001.

Marquis, Claudia. "Ariadne 'Down under': Margaret Mahy's The Tricksters." Marvellous Codes: The Fiction of Margaret Mahy. Ed. Elizabeth Hale \& Sarah Fiona Winters. Wellington: Victoria University Press, 2005.

--- "Margaret Mahy's 'Strong Characters"” Following the Looping Line: Exploring the Literary Legacy of Margaret Mahy (Conference Proceeding), 2006.

Morris, Tim. You're Only Young Twice. Urbana and Chicago: University of Illinois Press, 2000.

O'Flaherty, Wendy Doniger. Other Peoples' Myths: The Cave of Echoes. Chicago: University of Chicago Press, 1995.

Paul, Lissa. "Enigma Variations: What Feminist Theory Knows About Children's Literature." Signal 54 (1987): 186-201.

Perrault, Charles. "Bluebeard" Trans. Geoffrey Brereton. The Fairytales. Hammondsworth: Penguin, 1957.

Pohl, Michael. "Classical Myth and Margaret Mahy's Young Adult Fiction". Victoria University of Wellington, 2010.

Raburn, Josephine. "The Changeover, a Fantasy of Opposites." Children's Literature in Education 23.1 (1992): 27-38.

Raine, Katherine. "Domesticating the Land: Colonial Women's Gardening." Fragments: New Zealand Social and Cultural History. Ed. Bronwyn Dally and Bronwyn Labrum. Auckland: Auckland University Press, 2000. 76-96. 
Scally, Lisa. "'Tellling Stories of Desire': The Power of Authorship in the Changeover and the Amber Spyglass." Marvellous Codes: The Fiction of Margaret Mahy. Ed.

Elizabeth Hale \& Sarah Fiona Winters. Wellington: Victoria University Press, 2005.

Sherer, Susan. "Secrecy and Autonomy in Lewis Carroll." Philosophy and Literature 20.1 (1996): 1-19.

Sigler, Carolyn. Alternative Alices - Visions and Revisions of Lewis Carroll's Alice Books.

Lexington, Kentucky: The University Press of Kentucky, 1997.

Smith, Anna. "Contagious Knowledge: Margaret Mahy and the Adolescent Novel."

Marvellous Codes: The Fiction of Margaret Mahy. Ed. Elizabeth Hale \& Sarah Fiona

Winters. Wellington: Victoria University Press, 2005. 44-61.

Spufford, Francis. The Child That Books Built: A Life in Reading. London Faber \& Faber, 2002.

Stevenson, Robert Louis. Treasure Island. London: Puffin Classics, this edition: 2008, first published: 1883 .

Stowell, Phyllis. "We're All Mad Here." Children's Literature Association Quarterly 8.2 (1983): 5-8.

Tatar, Maria. Secrets Beyond the Door: The Story of Bluebeard and His Wives. Princeton: Princeton University Press, 2004.

Thompson, Mary Shine. "Introduction." Treasure Islands: Studies in Children's Literature.

Ed. Mary Shine Thompson and Celia Keenan. Dublin: Four Courts Press, 2006.

Waller, Alison. "'Solid All the Way through': Margaret Mahy's Ordinary Witches."

Marvellous Codes: The Fiction of Margaret Mahy. Ed. Elizabeth Hale \& Sarah Fiona

Winters. Wellington: Victoria University Press, 2005.

Walls, Kathryn. "Margaret Mahy: An Adlerian Reading." International Research in Children's Literature 1.2 (2008): 187-99. 
Weaver-Hightower, Rebecca. Empire Islands: Castaways, Cannibals, and Fantasies of Conquest. Minneapolis: University of Minnesota Press, 2007.

Wein, Elizabeth E. "Mystery in a House." The Lion and the Unicorn 24.2 (2000).

Winters, Sarah Fiona. "Aliens in the Landscape: Maori Space and European Time in Margaret Mahy's Fiction." Children's Literature Association Quarterly 33.4 (2008).

Wullschlager, Jackie. Inventing Wonderland: The Lives and Fantasies of Lewis Carroll, Edward Lear, J.M. Barrie, Kenneth Grahame and A.A. Milne. New York: The Free Press, 1995. 